\title{
Willingness to pay for unfamiliar public goods: Preserving cold-water coral in Norway.
}

\author{
Margrethe Aanesen*, Claire Armstrong*, Mikołaj Czajkowski ${ }^{\S}$, Jannike Falk- \\ Petersen*, Nick Hanley ${ }^{*}$ and Ståle Navrud ${ }^{\sharp}$
}

\begin{abstract}
The world's largest concentration of cold-water coral (CWC) is found off the Norwegian coast. Most CWC discoveries are recent, posing new challenges for Norwegian coastal and fisheries authorities regarding the management of deep-sea resources. Scientific knowledge of CWC is limited, and many citizens have not even heard about them. This creates problems for the application of stated preference methods to capture their economic value, and very few such studies have been conducted. To fill this gap, we designed a discrete choice experiment, which was implemented in a valuation workshop setting in order to derive estimates of participants' willingness to pay (WTP) for increasing the protection of CWC. Despite the fact that marine industries such as oil/gas and fisheries could be adversely affected by CWC protection, this did not reduce the respondents' willingness to pay for further protection. The possibility that CWC play an important role as habitat for fish was the single most important variable to explain respondents WTP for CWC protection. The survey revealed a high degree of preference heterogeneity, whilst we found an average WTP for CWC protection in the range of EUR 274-287.
\end{abstract}

JEL: Q51, Q 57

Key words: cold-water corals, willingness to pay, unfamiliar public good, discrete choice experiment, natural resource management

*Arctic University of Norway-UiT, P.O.Box 6050 Langnes, 9037 Tromso, Norway. Margrethe.aanesen@uit.no

$\S$ Department of Economic Sciences, University of Warsaw, Dluga 44/50, 00241 Warsaw, Poland

¥ Department of Geography and Sustainable Development, University of St Andrews, North st., St.Andrews, Fife KY 169AJ, UK

School of Economics and Business, Norwegian University of Life Sciences, P.O. Box 5003, 1432 As, Norway 
Marine organisms have long fascinated humans, as well as being of crucial importance for our wellbeing. Marine ecosystems provide supporting, provisioning, regulating and cultural ecosystem services as defined in the Millennium Ecosystem Assessment (MEA, 2005). Over recent decades, increasing awareness of the benefits our oceans provide has raised an interest in assessing the economic value of these goods and services, although due to their "hidden" nature, many of these benefits go un-noticed until they diminish (Stewart and Smout, 2013). Notwithstanding this, a number of studies have recently emerged which quantify the economic benefits of protecting marine species (Jobstvogt et al., 2014; Rogers, 2013; Hynes et al., 2013; Ressurreicao et al., 2011).

Tropical corals have been subject to a series of economic valuation studies (see e.g. Spurgeon, 1992, Pendleton, 1995, Parsons and Thur, 2007, Sarkis et al., 2012), and have been identified as the global biome with the highest valued ecosystem services in aggregate (de Groot et al., 2012). Their deepsea cousins, cold-water corals (CWC) have by contrast so far been subject to only one valuation effort, which was largely inconclusive (Glenn et al., 2010). Moreover, there are many more gaps in scientific knowledge of deep-sea ecosystems than for most terrestrial and coastal ecosystems (Ramirez-Llodra et al., 2011). Indeed, until quite recently our scientific knowledge about CWC and their functions in the deep-sea was very limited. The lack of scientific knowledge of CWC is reflected in the lower degree of public awareness of this resource, and less political pressure to conserve CWC compared to tropical corals. Nonetheless, during the last ten years, a substantial number of CWC protected areas have been established worldwide (Armstrong et al., 2014).

Although there are indications that CWC may provide habitat for some fish species (Stone 2006, Edinger et al., 2007), our knowledge about how CWC ecosystems function is far from complete. These knowledge gaps clearly complicate economic valuation of CWCs, as illustrated by the discrete choice experiment (DCE) study conducted by Glenn et al. (2010). Participants showed a low level of knowledge of CWC, which may partly explain the lack of statistical significance of the price attribute. Due to this statistically insignificant cost parameter, the authors stop short of estimating WTP for the attributes. In general, the participants in the Glenn et al. (2010) survey had a positive attitude towards protecting CWC areas, and preferred protecting all known and potential CWC areas as opposed to protecting only the known CWC areas. Further, the results showed that whereas the 
participants wanted to ban all trawling in CWC areas, they did in general not want to ban all fishing activities in these areas. Trawling is a particularly damaging form of fishing for CWC.

In a related study, Jobstvogt et al. (2014) value both non-use and use values attached to deep-sea environments around the coast of Scotland. They do not explicitly focus on CWC, although these habitats are found within their study area. The authors describe this deep-sea environment by attributes comprising the potential for organisms to contribute to the development of new medicines, and biodiversity expressed as number of marine species, which are protected. The authors argue that preferences for conserving such species represent non-use values ${ }^{1}$. They show that there is a positive WTP on the part of Scottish residents for both attributes, and that WTP for the "best" protection option is in the range of $£ 70-77$ per household per year.

We carried out our study in Norway, which has one of the highest densities of CWC in the world (IMR 2012). The exploration of the sea-bed off the Norwegian coast, partly by oil companies and partly by research institutions, has uncovered many CWC occurrences and reefs. According to the most recent assessments, 1100 CWC occurrences have been identified within the Norwegian exclusive economic zone (IMR 2012). These marine surveys have also shown that many CWC reefs are being adversely affected by human activities; at an early stage of the exploration, scientists estimated that $30-50 \%$ of the known CWC reefs had been damaged or impacted (Fosså et al., 2002). Threats to CWC include deep sea trawling, oil and gas exploration, mining and aquaculture. Today, as more CWC reefs have been discovered, the percentage of CWC sites found to be impacted may be lower, since CWC sites are now legally protected from bottom trawling as soon as they are identified. However, it is a fact that CWC have been, and still are being adversely impacted by commercial sea-bed operations, of which bottom trawling is the main culprit. Hence, improvements to the management of the ecosystem services provided by such biogenic habitats are of vital importance. At the same time, it is also necessary to present the social costs of further protection, which for the moment are potential losses in value added for the oil industry and the fisheries.

\footnotetext{
${ }^{1}$ This attribute is described in the survey as follows: "Animals such as deep-sea fish, starfish, corals, worms, lobsters, sponges, and anemones would benefit most from the protection."
} 
This paper reports the results of a stated preferences (SP) study valuing protection of CWC off the Norwegian coast in order to better include these types of resources in ocean management. The objective of the study is twofold: (i) to derive people's WTP for protection of CWC reefs in Norway, and (ii) to analyze what determines people's WTP for CWC protection. We conducted a discrete choice experiment (DCE) in a valuation workshop setting. A valuation workshop is a meeting of sampled participants, who complete choice tasks individually whilst learning about the good to be valued (MacMillan et al, 2006). This setting was chosen to reduce the challenges posed by the unfamiliarity of the good to be valued. Applying the Total Economic value (TEV) framework we identified indirect use values of CWC connected to their role as providing a habitat for fish (and other marine organisms); and non-use values connected to the role CWC play for biodiversity and as an organism, which people might value for its own sake as two components of TEV. However, we cannot neatly disentangle the values people hold for CWC due to their role as habitat and the value related to their mere existence. In section 2 we present the attributes of the DCE, and give an introduction to the methods used and the dataset. Section 3 presents the results, section 4 discusses the results and section 5 concludes.

\section{$2 \quad$ Methods and data}

\section{$2.1 \quad$ Methods}

CWC is a good unfamiliar to most people. In order to overcome problems connected to the fact that people are not well informed about the good they are about to value, it was decided to use the valuation workshop method of stated preference data collection, instead of postal, internet or faceto-face interviews. ${ }^{2}$ A valuation workshop departs from interviews and postal/web surveys by more extensive provision of information about the good to be valued in a group setting, repeated valuation procedures and time to think and deliberate between the valuation tasks (Macmillan et al., 2002; MacMillan et al., 2006; Colombo et al., 2013). Valuation workshops are usually performed within a geographically concentrated area. As our study covers the whole country (Norway) and in order to be manageable, each respondent was only asked to state their values on one occasion (although this included the completion of multiple choice sets). The main difference between

\footnotetext{
${ }^{2}$ See e.g. Macmillan et al. (2002) and Christie et al. (2006) for problems connected to stated preference studies of unfamiliar goods conducted using face-to-face interviews or mail shots. Valuation workshops are also sometimes called the market stall method (Macmillan et al., 2002).
} 
valuation workshops and face-to face interviews, postal or internet web survey is the enhanced provision of information and people's opportunity to ask questions about unfamiliar goods. In our study each workshop involved the following steps: 1) a 30-minute power point presentation concerning CWC, where the participants could ask clarifying questions regarding CWC or the survey, 2) participants individually completed the questionnaire. Each workshop lasted about 2 hours.

In the selection of the choice attributes we used results from existing literature and expert interviews. Foley et al (2010) showed that identified ecosystem services connected to CWC are i) as raw material and ornamental resources (direct use and option values), ii) habitat functions, including refuge and nursery functions (indirect use values), and iii) non-use values. In the only previous SP survey which has been implemented on CWC (Glenn et al 2010), the effects of CWC-protection on off-shore industrial activities was included. As there is substantial off-shore industrial activity in the form of oil and gas exploitation and fisheries taking place along the Norwegian coast, we found that including this aspect in our survey was timely. Based on this, it was decided to initially include "size of protected area" to represent non-use values of CWC, and "habitat for fish" to represent indirect use values, and "raw material in medicinal products" to represent direct use values or option values, as this use is negligible as of today. Assuming that protection would imply a total ban of all industrial activities in the protected area, we used the attribute "attractive for industrial activities" to represent the societal costs of CWC protection.

Prior to the final design of the survey we implemented 3 focus groups with experts and 2 focus groups with "the general public", each consisting of 5-10 participants to get feedback on the selection of attributes. Whereas none of the groups opposed the choice of attributes, each of the groups commented on the rather complex choice situation with 5 attributes, some of which taking more than two levels. Based on this feedback it was decided to reduce the number of attributes, and their levels.. As the use of CWC as input in medicinal products is the most speculative value connected to CWC, this attribute was removed. This yielded a design with two attributes representing the benefits we may attach to CWC and two attributes representing costs to society and the individual of further CWC protection. Table 1 shows the four attributes and the levels they take. 
157 At the time of writing, nine CWC areas are legally protected in Norwegian waters, covering a total of $2445 \mathrm{~km}^{2}$. This area is used as the reference level for the attribute Size. In addition to CWC reefs, these sites also encompass buffer zones around the reefs. The attribute Size refers to the total protected area, not the additional area protected. It takes two alternative levels; $5000 \mathrm{~km}^{2}$ and 10 $000 \mathrm{~km}^{2}$, where the former expresses a realistic estimate of how large areas of CWC could easily be protected as of today, and the latter represents an upper limit for CWC area which could realistically be protected. Note that the size of protected area encompasses both the CWC occurrences and buffer zones.

The most important off-shore commercial activities along the Norwegian coast which pose the largest threats to CWC are commercial fisheries and oil and gas extraction. The area presently protected includes some locations, which are attractive for oil and gas exploration and for fisheries activities, and some which are not. The attribute commercial thus distinguishes between whether areas eligible for future protection are attractive to these commercial activities or not. ${ }^{3}$

The CWC sites currently protected may also include some areas which are of considerable importance as habitat for fish (including both commercially caught species and other species), and some which are of less importance. The habitat attribute distinguishes between areas being highly important as a habitat for fish, compared to areas that are of less importance to fish. Finally, whereas the cost of maintaining the present size of protected CWC area is set to zero in the design, increasing the area of protection is assumed to imply an additional cost. The cost attribute takes four possible levels, and varies between NOK (Norwegian kroner) 100 and 1000 per household annually. ${ }^{4}$ The payment vehicle we used is a uniform nominal increase in the annual federal tax.

Our DCE design included 12 choice tasks per respondent. We prepared the choice sets by maximizing 182 the expected Bayesian d-efficiency of a multinomial logit model (Scarpa and Rose 2008). The design 183 was updated after the pilot and twice throughout the main study, in order to utilize more precise

\footnotetext{
${ }^{3}$ Although we merged the two industries into one attribute in the choice card, the two industries were given individual attribute levels (important/not important area) such that they could easily be separated into two dummy variables in the statistical model (see table 1 for the levels for this attribute).

${ }^{4}$ The nominal exchange rate for Euro against Norwegian kroner is 8.4 (July 2014).
} 
184

information about respondents' preferences as informative priors. An example of a choice card is provided in Appendix A.

Altogether, 402 persons, including two pilot groups, were surveyed. Of these, 5 persons did not complete any of the choice cards and were thus eliminated from the sample. The remaining 397 respondents provided us with 4683 choice observations. In addition to the choice cards, the questionnaire also contained socio-demographic (SD) variables (gender, age, place of residence, education level, participation in the labor force, occupation, household size and personal and household income), and questions regarding attitudes towards environmental protection in general. ${ }^{5}$

The theoretical foundation for DCE is random utility theory, which assumes that the utility a person derives from CWC protection depends on observed characteristics and unobserved idiosyncrasies, represented by a stochastic component (McFadden, 1974). When the survey respondents are indexed $n$, the alternative $j$, and the choice situation $t$, the utility to individual $n$ of choosing alternative $j$ in situation $t$ can be expressed by

$$
V_{n j t}=\alpha_{n} p_{n j t}+\boldsymbol{b}_{n}^{\prime} \boldsymbol{X}_{n j t}+e_{n j t},
$$

where the utility expression is separable in price, $p_{n j t}$, and other non-price attributes, $\boldsymbol{X}_{n j t}$, and $e_{n j t}$ is a stochastic component allowing for other factors than those observed by an econometrician to affect individuals' choices.

Two things in the above specification need to be noted. First of all, $\boldsymbol{\alpha}_{\boldsymbol{n}}$ and $\boldsymbol{b}_{n}$ are individual-specific, thus allowing for heterogeneous preferences amongst respondents and leading to a mixed logit model (MXL). ${ }^{6}$ Assuming that they are the same for all respondents implies homogenous preferences and leads to the basic multinomial logit model (MNL), which although very restrictive, is typically a starting point for econometric analysis of DCE data.

\footnotetext{
${ }^{5}$ The questionnaire is available from the corresponding author upon request.

${ }^{6}$ Is it typically assumed that individual parameters follow a particular distribution (possibly multivariate distribution allowing for non-zero correlation of model parameters).
} 
Secondly, the stochastic component of the utility function $\left(e_{n j t}\right)$ is of unknown, possibly

211 heteroskedastic variance $\left(\operatorname{var}\left(e_{n j t}\right)=s_{n}^{2}\right)$. Identification of the model is typically assured by

212 normalizing this variance, such that the error term $\varepsilon_{n j t}=e_{n j t} \cdot \frac{\pi}{\sqrt{6} s_{n}}$ is identically and independently

213 extreme value type one distributed (with constant variance $\operatorname{var}\left(\varepsilon_{n j t}\right)=\pi^{2} / 6$ ), leading to the 214 following specification:

$$
U_{n j t}=\sigma_{n} \alpha_{n} p_{n j t}+\sigma_{n} \boldsymbol{b}_{n}^{\prime} \boldsymbol{X}_{n j t}+\varepsilon_{n j t} .
$$

Note that due to the ordinal nature of utility, this specification still represents the same preferences. The estimates $\sigma_{n} \alpha_{n}$ and $\sigma_{n} \boldsymbol{b}_{n}$ do not have direct interpretation anyway, but if interpreted in relation to each other the scale coefficient $\left(\sigma_{n}=\pi / \sqrt{6} s_{n}\right)$ cancels out.

Finally, given the interest in establishing estimates of WTP for the non-monetary attributes $\boldsymbol{X}_{n j t}$, it is convenient to introduce the following modification which is equivalent to using money-metric utility function (aka estimating the parameters in WTP space; Train and Weeks, 2005):

$$
U_{n j t}=\sigma_{n} \alpha_{n}\left(p_{n j t}+\frac{\boldsymbol{b}_{n}{ }^{\prime}}{\alpha_{n}} \boldsymbol{X}_{n j t}\right)+\varepsilon_{n j t}=\sigma_{n} \alpha_{n}\left(p_{n j t}+\boldsymbol{\beta}_{n}{ }^{\prime} \boldsymbol{X}_{n j t}\right)+\varepsilon_{n j t} .
$$

Note that under this specification the vector of parameters $\boldsymbol{\beta}_{n}=\boldsymbol{b}_{n} / \alpha_{n}$ is now (1) scale-free and (2) can be directly interpreted as a vector of implicit prices for the attributes $\boldsymbol{X}_{n j t}$. Also, in MXL models an additional advantage of this specification is that the econometrician is able to specify a particular distribution of WTP in the sample (by specifying the distribution of $\boldsymbol{\beta}_{n}$ ) rather than the distribution of the underlying taste parameters $\left(\boldsymbol{b}_{n}\right)$. These taste parameters are later divided by a (possibly also random) price coefficient, indirectly leading to often implausible assumptions about the distribution of WTP in the sample.

Estimation of the model parameters is through maximum likelihood techniques. An individual will choose alternative $j$ if $U_{n j t}>U_{n k t}$, for all $k \neq j$, and the probability that alternative $j$ is chosen from a set of $C$ alternatives is given by 


$$
P(j \mid C)=\frac{\exp \left(\sigma \alpha_{n}\left(p_{n j t}+\boldsymbol{\beta}_{n}^{\prime} \boldsymbol{X}_{n j t}\right)\right)}{\sum_{k=1}^{C} \exp \left(\sigma \alpha_{n}\left(p_{n k t}+\boldsymbol{\beta}_{n}^{\prime} \boldsymbol{X}_{n k t}\right)\right)} .
$$

In the simple (fixed parameter) multinomial logit (MNL) model the $n$-subscript of all parameters can be suppressed so that the estimated parameters are no longer individual specific. In the MXL specification, since the probability is conditional on the random terms the unconditional probability is obtained by multiple integration, and there exists no closed form expression of (4). Instead, it can be simulated by averaging over $D$ draws from the assumed distributions (Revelt and Train, 1998). As a result, the simulated log-likelihood function becomes:

$$
\log L=\sum_{n=1}^{N} \log \frac{1}{D} \sum_{d=1}^{D} \prod_{t=1}^{T_{i}} \frac{\exp \left(\sigma \alpha_{n}\left(p_{n j t}+\boldsymbol{\beta}_{n}^{\prime} \boldsymbol{X}_{n j t}\right)\right)}{\sum_{k=1}^{c} \exp \left(\sigma \alpha_{n}\left(p_{n k t}+\boldsymbol{\beta}_{n}^{\prime} \boldsymbol{X}_{n k t}\right)\right)}
$$

Whereas the model above yields estimates for marginal WTPs for the attributes, we are also interested in the total WTP for the protection alternatives relative to no further protection. This corresponds to the compensating surplus (variation) of protection, which can be calculated using Hanemann (1984) and Small et al. (1981) approach with minor modifications for WTP-space models. ${ }^{7}$ As the size attributes are mutually exclusive, we present the welfare measures associated with two exemplary cases - the first, denoted 'small' protection, and the second denoted 'large' protection, which differ in size (size5 or size10, respectively) and include all the other choice attributes (oil/gas, fish, habitat).

\section{$2.2 \quad$ Data}

A professional survey firm was employed to recruit the workshop participants. In the recruitment process the targeted persons were told that the survey was about management of marine resources, but not that it was about CWC. In addition, they were told that there was a payment of NOK 500 (about EUR 60) for each participant who completed the survey. In order to secure statistical representativeness with respect to gender and age, each group is representative with respect to

\footnotetext{
${ }^{7}$ Note that since we are discussing a public program of protecting CWCs we are effectively dealing with a one alternative situation; CWCs are at their current state vs. implementing a new program, which simplifies calculations further.
} 
gender and age for their respective municipality. To secure geographic coverage we sampled municipalities across the whole country. Altogether 24 valuation workshops (including 2 pilots) in 22 municipalities were conducted. Each workshop had between 12 and 23 participants.

The sample characteristics are given in table 2.

(Table 2 about here)

The sample has a somewhat lower female share (46.5\%) compared to the national average (49.8\%). The age distribution of our sample is very close to the national age distribution, but we have a lower share in the youngest group (18-25 years) and a slightly higher share in the middle aged group (46-55 years). Based on postal code we calculated the percentage living in coastal areas (63\%) and in urban areas (73\%). Both are somewhat higher compared to the national average. About $63 \%$ of the survey sample belongs to the labor force, whereas the national share is $73 \%$. Occupationally, the survey sample is biased. Of those working in the private sector, the sample contains a higher share of those belonging to the oil/gas industry, fisheries and aquaculture (8\%), whereas it is lower for all other industries, including services. This self-selection into the sample is as expected as the topic for the survey is marine resources, and therefore may be perceived as more relevant for those employed in marine industries. The respondents were divided into ten income groups, each of an interval of NOK 100k (EUR 11.9k) and eight household income groups, each of an interval of NOK 200k (EUR 23.8k) except the first and last group. The survey has a lower percentage of low income people compared to the national average. The sample is biased towards more educated people, $57 \%$ had more than 12 years in school compared to the national average on $26 \%$. Finally, only about $10 \%$ of the survey participants were members of an environmental NGO.

As part of the survey all participants were asked to answer a quiz with eight questions. The quiz was given immediately after the PP-presentation of CWC, and the quiz questions referred to information, which was given during the presentation. Almost $30 \%$ of the participants achieved a full score, whereas another $28 \%$ scored 7 out of 8 , and $25 \%$ scored 6 out of 8 . Hence, only about $20 \%$ got 5 or less of the 8 quiz questions correct. This shows that the PP-presentation was reasonably effective in informing people about the aspects of CWC relevant for the valuation exercises, compared for example with respondents in Glenn et al. (2010). 


\section{$291 \quad 3 \quad$ Results}

292 In the DCE, the status quo was chosen in $25 \%$ of the choices, and in the remaining $75 \%$ of the

293 choices protecting a larger area was chosen. Table 3 shows the estimation results for the MXL model

294 with correlations, and for comparison, also for the MNL model. All models are formulated in WTP-

295 space and hence the parameter estimates for all non-price attributes can be directly interpreted as

296 WTP amounts. In the MXL model we assumed that the marginal WTPs are normally distributed, whereas the cost attribute is assumed to be log-normally distributed. ${ }^{8}$

298

(Table 3 about here)

Table 3 shows that in the MXL model all attributes are significant and so are their associated standard deviations, which is an indication of respondents' unobserved preference heterogeneity. The habitat attribute had the highest WTP. Respondents were willing to pay EUR 166 more for protection when the protected area was important habitat for fish compared to when it was not. The estimated WTP for the oil and the fisheries attributes were positive, which means that if the area was attractive for the fisheries and/or for the oil industry people were willing to pay EUR 39 and EUR 16 respectively more for its annual protection, compared if it was not important for these off-shore industries. Finally, regarding the size of the protected area, respondents were willing to pay EUR 53 for extending the protected area from the current $2445 \mathrm{~km}^{2}$ to $5000 \mathrm{~km}^{2}$, and EUR 66 for an extension from 2445 to $10000 \mathrm{~km}^{2}$. The MNL model, on the other hand, yields significant WTPs for only three of the attributes in addition to cost; size (large), fisheries and habitat. The "size" attributes in this model have far lower marginal WTPs compared to the MXL model, indicating that these were the attributes which had the highest correlation with other attributes (the results from the MXL model without correlation were closer to the MNL results for these attributes than to the MXL model with correlation).

\footnotetext{
${ }^{8}$ We have made our dataset and codes available at http://uit.no/prosjekter/prosjekt?p document id=349718 and czaj.org for others to be able to replicate our results.
} 
317 We also estimated an MNL and an MXL model in which the choice attributes are separately 318 interacted with each of the socio-demographic (SD) variables. This allows us to identify gross (i.e., 319 without controlling for differences in the SD variables) effects of each of these variables. These results are included in appendix B. ${ }^{9}$ Most of the parameters for the interaction variables are not significant. Among the significant effects we find that unemployed persons and persons in households with higher total household income were more likely to choose the SQ alternative, whereas retired persons were more likely to choose further protection. Male respondents and those with higher personal income were willing to pay more for the fisheries attribute, whereas older respondents were willing to pay less for the fisheries attribute. People working in the oil industry and in the public sector and people living at the coast were willing to pay more for the habitat attribute. There were no statistically significant differences between respondents living in urban areas compared to rural households.

Next, we illustrate our results by simulating WTP for two protection scenarios. We call these "small" and "large", and arrange it so that they differ only in the size of newly protected CWC, but in both cases the areas are important for commercial activities (oil/gas and fisheries) and as habitat for fish. The procedure we used took uncertainty with respect to model parameters into account. The results present the mean, standard error (approximated with the standard deviation) and 95\% confidence interval (approximated with the 95\% inter-quantile range) of the welfare measures of the two scenarios described above. The results, based on the MNL model and the MXL model with correlations are presented in Table 4.

\footnotetext{
${ }^{9}$ Note that, due to the huge amount of parameters the models where the attributes are interacted with the SD for work and occupation are the MXL model without correlations. For all other interaction models the MXL model with correlations are applied.
} 
341 The WTP for the two protection scenarios resulting from the MNL model is reasonably close to that

342 for the MXL model. The simulated WTP for a small and a large degree of protection of cold water 343 corals equals EUR 274 and EUR 287 per household per year respectively. ${ }^{10}$

\section{Discussion}

346 There may be trade-offs between protecting CWC and the benefits which society derives from other

347 services provided by the marine environment such as commercial deep-sea fisheries and petroleum.

348 From a management and policy perspective, it is thus of considerable interest to identify types of

349 ecosystem service values to which CWC may contribute and their economic significance. Foley et al.

350 (2010), applying the TEEB framework (The Economics of Ecosystems and biodiversity; TEEB, 2010), ${ }^{11}$

351 identify several ecosystem services (ES) that CWC provide. Whereas we have derived significant

352 estimates on peoples' WTP for CWC protection, it is hard to match these values to specific ecosystem

353 services that this resource provides. The most obvious ecosystem service provided by CWC is a

354 habitat for fish (and other marine organisms), which is an intermediate or supporting ecosystem

355 service. The largest single value for CWC off the coastline of Norway is people's WTP for protecting

356 CWC because of this importance as a habitat for fish, perhaps due to preferences related to the

357 consumption of fish. The single value attached to the attribute habitat is four times higher than the

358 value attached to the fisheries attribute and two to three times higher than the size attributes. The

359 habitat attribute may, however, also relate to non-use values for fish.

361 This interpretation arises from the fact that the attribute fisheries has a positive sign. This means that

362 even if protecting CWC will imply reduced fisheries activities, and thus less fish for consumption,

363 people are still willing to pay for protecting CWC. Hence, people are not only willing to pay for

364 protecting CWC because then we get more fish to eat; they may also be willing to pay for protecting

365 CWC because there will be more fish regardless of whether we eat them or not. So, people value

366 CWC due to its role as habitat for fish not only because fish provides food (and generate income) for

367 them, but also because they care about the existence of fish. We are not able to disentangle these

\footnotetext{
${ }^{10}$ Note that the WTP for an aggregate scenario is not a simple sum of WTP for separate attributes, since the parameters in the MXL model could be correlated. In order to calculate the WTP we applied a two-tier simulation procedure described in Czajkowski et al. (2015).

${ }^{11}$ TEEB in turn applies the TEV (Total Economic Value) to categorize the ecosystem services to be valued.
} 
two motives for WTP. The size attributes (small and large) have significant WTP estimates. Although it could be tempting to let these attributes represent peoples' valuation of CWC for its pure existence (non-use) values, this attribute could also represent the fact that a larger protected area means that there is more habitat for fish and other marine organisms. As such, the size attributes may also encompass intermediate (indirect) ecosystem service values. Given the relatively high welfare level of most people in Norway, it is not unlikely that immaterial concerns play a significant role in peoples' preferences. One such immaterial concern is to safely assume that CWC will continue to exist in Norwegian waters, and that it will continue to provide habitat for fish stocks in the future.

Due to the complexity of the model and number of observations, including the socio-demographic characteristics as interactions in the model did not provide many significant results. Among those of interest is the fact that men, younger people and those with higher income tended to have higher WTP for the fisheries attribute, whereas people living on the coast, working in the oil industry or working in the public sector had a higher WTP for the habitat attribute. We did not find statistically significant effects of the rural-urban gradient, which has been shown to be a significant explanatory variable in other valuation studies (Martin-Lopez et al., 2012). Neither did we find large gender gaps, such as Funk and Gathmann (2008) found in areas such as health, environmental protection, defence spending and welfare policy.

Wilson and Howarth (2002) point to a paradox that, whereas most ecosystem services are public goods, the methods applied to elicit how people value them are based on responses from individuals in private settings. In contrast, group settings can encourage people to share their knowledge, which in turn increases the likelihood of more informed choices than would be the case if the decision were left to single individuals (Winquist and Larson, 1998, referred to in Wilson and Howarth, 2002, p.439). This may be especially relevant in cases with unfamiliar (public) goods, such as CWC. Spash (2002) adds nuances to this viewpoint by showing that additional information mainly contributes to inform respondents' preferences rather than changing them. Group discussion of the trade-offs which society faces in environmental management decisions can also produce more consensus over actions, even when preferences are elicited on an individual basis. The fact that previous studies of CWC protection have ended up inconclusive due to a non-significant cost attribute (Glenn et al., 2010) was a strong signal that the "minimum information" modes of WTP elicitation, such as postal, 
399 internet, or even face to face (in-person) surveys may not be sufficient to derive useful WTP

400 estimates for CWC management, since this is such an unfamiliar good (Czajkowski et al., 2015).

401 Given this background, we chose a valuation workshop approach, which worked well in the sense 402 that it gave us a robust dataset and significant attribute estimates. This said, it must be admitted that 403 the costs of the survey were significant. Recent experiences have shown that an identical survey, but where all information was provided by the use of videos, can be implemented by the use of internet for only a fraction of the valuation workshop costs (Sandorf et al., 2014). The question is, however, whether such an internet survey could have been implemented without the experiences from the valuation workshops? As we see it, the benefits from implementing valuation workshops were not solely more robust and better informed WTP estimates, but also a learning process for SPpractitioners when valuing unfamiliar (environmental) goods. Whereas focus groups provide information about how to present the good to be valued, and the pilot(s) control for how respondents manage to make "reasonable" choices, nowhere in the process of designing an SPsurvey do researchers have the opportunity to be informed about how people actually understand the questions they are asked to respond to.

Valuation workshops do not come without drawbacks. Although the sample is relatively representative for the Norwegian adult population with regard to socioeconomics and geography, two issues may still make the sample un- representative of the general public. i) Prior to the choice experiment questions the participants were given information about CWC, and ii) the survey participants were allowed to ask questions regarding CWC and deliberate on the issues around protecting such sites. These issues obviously imply that the survey sample on average is more informed about CWC than the Norwegian public in general. This is important since results from the valuation literature show a positive correlation between the level of knowledge of a good and the WTP for the same good (Spash 2002, LaRiviere et al., 2014). In addition we have the so-called "social desirability" effect, which states that people tend to increase their stated WTP for a good when given in a social setting compared to when they are surveyed in social isolation (List et al., 2004, Leggett et al., 2003).

Based on the results from the survey reported above, the message to Norwegian coastal authorities is that people do care for CWC per se, and especially if it constitutes an important habitat for fish. Also, they are willing to accept that commercial fishing and the oil industry are adversely affected by 
CWC protection. Norwegian coastal authorities and managers emphasize the importance of implementing policy, which to the extent possible, is accepted by those who are subject to these rules and regulations (pers. comm. Egil Lekven, Norwegian Directorate of Fisheries, 28.09.2012). Hence, the authorities are particularly sensitive to the feedback from fishers and other people working in the marine industries. Our results show that people working in the oil industry had a higher WTP for the habitat attribute compared to people working in other industries. In addition, $54 \%$ of the respondents working in marine industries (fisheries, aquaculture and oil exploitation) state that industrial activities off shore must be executed with care in order to make as little damage to CWC as possible. The remaining $46 \%$ of respondents working in the marine sector state that we have to accept that some CWC may get lost due to industrial activities. The corresponding numbers for respondents not working in the marine industries are $68 \%$ and $32 \%$. Hence, although respondents from marine industries are to a larger degree willing to accept that CWC are destroyed due to industrial activities, a majority still are of the opinion that such activity must be executed with outmost care in order to avoid damage to CWC. Such a result is of interest for the authorities, as it indicates that protecting areas with CWC from, first and foremost, bottom trawling may gain support from those who have to live with the consequences of the regulations. On the other hand, as only $8 \%$ of the respondents belong to the marine sector, and given the problems of self-selection and the knowledge bias, this result must be interpreted with care.

\section{Conclusions}

451 An increasing awareness that human welfare crucially depends on ecosystem services beyond our 452 daily experiences renders information about these unfamiliar and inconspicuous goods and services 453 highly important. The results presented in this paper show that further protection of CWC is regarded as a benefit for which people have a positive and significant WTP. In addition, although not yet rigorously scientifically proven, scientists suspect that CWC is important habitat for many commercially important species. These aspects make CWC important from a management perspective. The aim of this paper is to derive monetary estimates for people's valuation of CWC, and to determine the motivations behind the derived WTP. The results revealed that people value CWC due to the fact that CWC provide habitat for fish (and other marine organisms), and for its pure existence. However, we were not able to disentangle the values people attach to CWC due to its role as habitat for fish compared to its pure existence. 
There are challenges in valuing intangible, and for most people unheard of, organisms. In the worst case, we may end up with an invalid dataset, because the respondents have not understood what they were responding to. To avoid this pitfall, we implemented the survey as a type of valuation workshop instead of a traditional stated preferences survey. Whereas this rendered the survey highly valid, it came at the cost of possible sample bias due to self-selection and knowledge acquisition and the social desirability effect.

This paper presents the first direct monetary valuation of CWC. Such a valuation of an intangible and relatively unknown good poses several methodological and practical challenges as described above. On the other hand, it has provided insights, which can be useful in the management of marine resources in Norway. First, we show that people in Norway derive welfare from knowing that CWC exists. Second, assuming that CWC plays a role as habitat for fish, we show that people motivation for protecting CWC is not only motivated by the fact that they consume fish, but also that they value fish having good and sufficient living conditions. Our results indicate that such considerations should be given significant weight in Norwegian resource management. Finally, our work illustrates the challenges inherent in the alignment of the MEA (2005) classification of ecosystem services with the older concept of Total Economic Value (TEV).

\section{Acknowledgements}

The work on this paper is carried out in the project "Habitat-Fisheries interactions: Valuation and bioeconomic modeling of cold water corals" financed by the Norwegian Research Council, grant \# 216485. We would like to thank the participants of 5 focus groups and 24 valuation workshops for their time and effort to provide valuation data on the CWC. We are grateful to Jan Helge Fosså and Pål Buhl Mortensen for valuable input regarding the ecological aspects of CWC. We also thank four referees and an editor for their comments to a previous version of the paper. All errors are our own. 


\begin{tabular}{l} 
Attribute \\
$\begin{array}{l}\text { Size of protected } \\
\text { area (total) }\end{array}$ \\
\hline $\begin{array}{l}\text { Attractiveness for } \\
\text { commercial } \\
\text { activities }\end{array}$ \\
\hline $\begin{array}{l}\text { Importance as } \\
\text { habitat for fish }\end{array}$ \\
\hline $\begin{array}{l}\text { Costs per household } \\
\text { per year }\end{array}$ \\
\hline I prefer
\end{tabular}

\begin{tabular}{|c|c|c|c|}
\hline & Alternative 1 & Alternative 2 & $\begin{array}{l}\text { Alternative } 3 \\
\text { (SQ) }\end{array}$ \\
\hline & $5.000 \mathrm{~km}^{2}$ & $10.000 \mathrm{~km}^{2}$ & $2.445 \mathrm{~km}^{2}$ \\
\hline 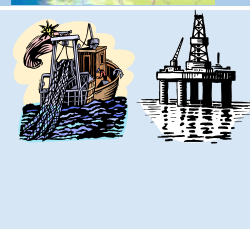 & $\begin{array}{l}\text { No, not } \\
\text { attractive for } \\
\text { any } \\
\text { commercial } \\
\text { activities }\end{array}$ & $\begin{array}{l}\text { Attractive for } \\
\text { oil/gas and } \\
\text { fisheries }\end{array}$ & $\begin{array}{l}\text { Somewhat } \\
\text { attractive for } \\
\text { oil/gas and } \\
\text { fisheries }\end{array}$ \\
\hline & Important & Not important & Some importance \\
\hline & $100 \mathrm{kr} /$ year & $1000 \mathrm{kr} /$ year & 0 \\
\hline & & & \\
\hline
\end{tabular}

492 Figure A1 Choice card used in the DCE 
494

495

496 Table A1

497

498

\begin{tabular}{|c|c|c|c|}
\hline & \multirow{3}{*}{$\begin{array}{c}\text { MNL model } \\
\text { Coefficient } \\
\text { (s.e.) } \\
-1.5995\end{array}$} & \multicolumn{2}{|c|}{ MXL model } \\
\hline & & $\begin{array}{c}\text { Mean } \\
\text { (s.e.) }\end{array}$ & $\begin{array}{c}\text { Std.dev. } \\
\text { (s.e.) }\end{array}$ \\
\hline & & $73.0686 * * *$ & $202.4771^{* * *}$ \\
\hline \multirow[t]{2}{*}{ Small-size } & (14.8912) & $(15.5776)$ & (20.1415) \\
\hline & $40.8928 * * *$ & $99.5739 * * *$ & $233.0997 * * *$ \\
\hline \multirow[t]{2}{*}{ Large-size } & (14.8719) & (15.6675) & $(20.7660)$ \\
\hline & $23.3791 * *$ & 16.9129 & $98.2431 * * *$ \\
\hline \multirow[t]{2}{*}{ Oil/gas } & (9.8471) & (9.3039) & (8.3238) \\
\hline & 13.3119 & 11.8287 & $105.7522 * * *$ \\
\hline \multirow[t]{2}{*}{ Fish } & (10.1590) & (8.3010) & (8.5319) \\
\hline & $175.3952 * * *$ & $159.5201^{* * *}$ & $216.9765^{* * *}$ \\
\hline \multirow[t]{2}{*}{ Habitat } & (16.9902) & (15.1114) & (20.9028) \\
\hline & -21.7111 & -3.1876 & $235.1352 * * *$ \\
\hline \multirow[t]{2}{*}{ Small-size*sex } & (20.1577) & (26.8175) & (30.7155) \\
\hline & -38.3644 & -24.4888 & $239.5579 * * *$ \\
\hline \multirow[t]{2}{*}{ Large-size*sex } & $(20.4352)$ & (29.1217) & (31.8762) \\
\hline & -21.3664 & -4.6147 & $71.8871 * * *$ \\
\hline \multirow[t]{2}{*}{ Oil/gas*sex } & (13.4468) & (13.3909) & $(12.7528)$ \\
\hline & $28.7139 * *$ & $32.2458 * *$ & $91.7690 * * *$ \\
\hline \multirow[t]{2}{*}{ Fish*sex } & (14.0689) & $(12.9890)$ & (15.4364) \\
\hline & -2.0932 & -6.2462 & $173.1844^{* * *}$ \\
\hline Habitat*sex & (14.9574) & (20.0993) & $(25.0731)$ \\
\hline $\begin{array}{l}\text { Price (in preference } \\
\text { space) }\end{array}$ & $\begin{array}{l}77.1318^{* * *} \\
(6.4918)\end{array}$ & $\begin{array}{l}72.7213^{* * *} \\
(8.8205)\end{array}$ & $\begin{array}{c}110.6386 * * * \\
(10.5950)\end{array}$ \\
\hline$N$ & 4683 & & 4683 \\
\hline
\end{tabular}

500

MNL: LogLikelihood $=-4753.2124, A / C / n=2.0347$, pseudo $-R 2=0.0639$
Marginal willingness to pay (WTP) estimates in Euro resulting from the MNL and MXL models including interactions with respondents' gender. ${ }^{* * *},{ }^{* *}$ and

* indicate estimates significant at 1\%, 5\% and $10 \%$ level, respectively. 
502 Table A2

503

504

Marginal willingness to pay (WTP) estimates in Euro resulting from the MNL and MXL models including interactions with respondents' age. ${ }^{* * *},{ }^{* *}$ and ${ }^{*}$ indicate estimates significant at 1\%,5\% and 10\% level, respectively.

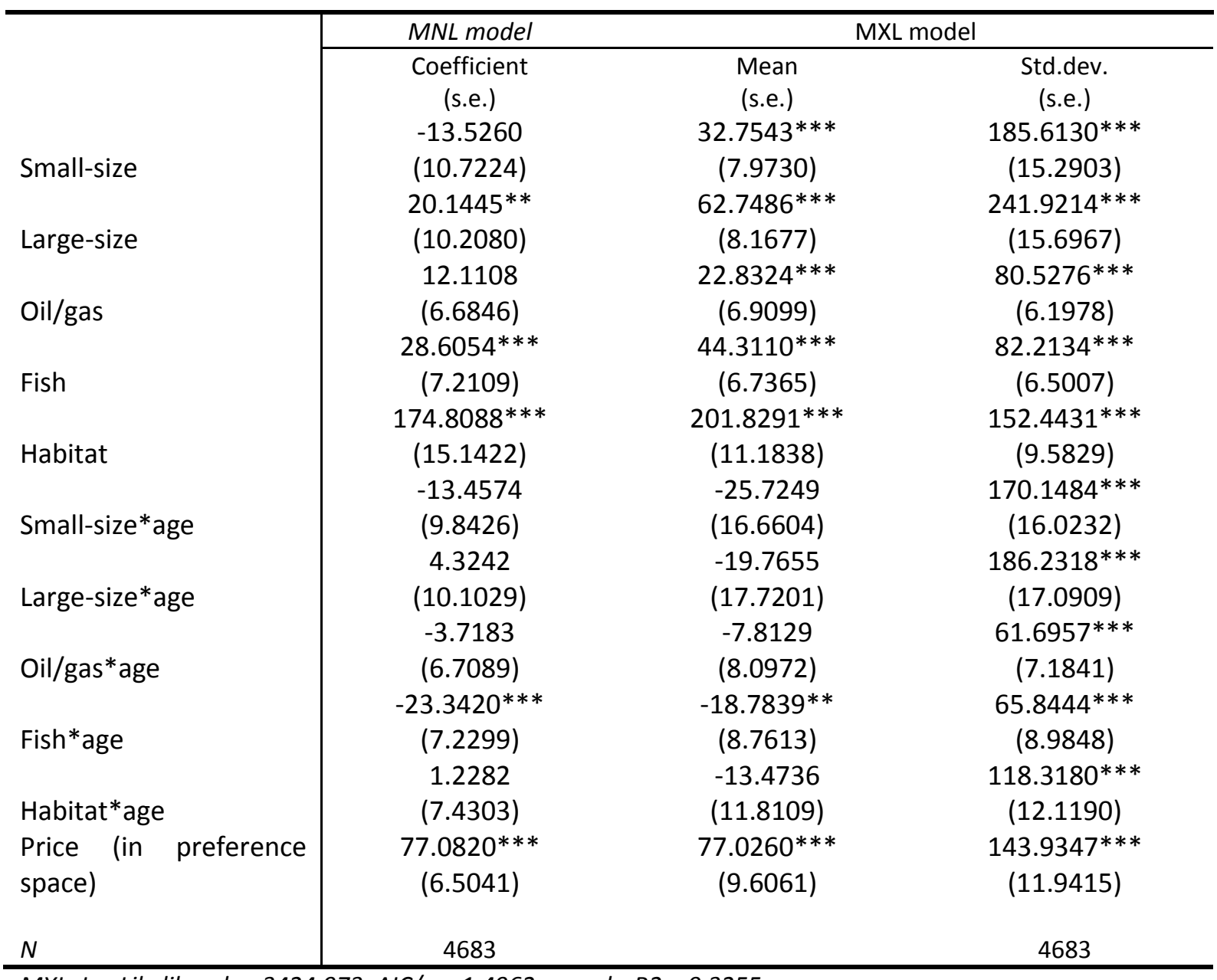

505 MXL: LogLikelihood $=-3424.973, A / C / n=1.4962$, pseudo $-R 2=0.3255$

506 MNL: LogLikelihood $=-4747.098, A I C / n=2.0321$, pseudo $-R 2=0.0651$ 
$508 \quad$ Table $A 3$

509

510

511

Marginal willingness to pay (WTP) estimates in Euro resulting from the MNL and MXL models including interactions with respondents being members of environmental non-government organizations. ***, ** and * indicate estimates significant at $1 \%, 5 \%$ and $10 \%$ level, respectively.

\begin{tabular}{|c|c|c|c|}
\hline & \multirow{2}{*}{$\begin{array}{l}\text { MNL model } \\
\text { Coefficient } \\
\text { (s.e.) }\end{array}$} & \multicolumn{2}{|c|}{ MXL model } \\
\hline & & $\begin{array}{l}\text { Mean } \\
\text { (s.e.) }\end{array}$ & $\begin{array}{l}\text { Std.dev. } \\
\text { (s.e.) }\end{array}$ \\
\hline & -20.1593 & $32.7543 * * *$ & $185.6130 * * *$ \\
\hline \multirow[t]{2}{*}{ Small-size } & (11.2388) & (7.9730) & (15.2903) \\
\hline & 12.6377 & $62.7486 * * *$ & $241.9214^{* * *}$ \\
\hline \multirow{2}{*}{ Large-size } & (10.6727) & (8.1677) & (15.6967) \\
\hline & 8.5732 & $22.8324 * * *$ & $80.5276 * * *$ \\
\hline \multirow[t]{2}{*}{ Oil/gas } & (7.0188) & (6.9099) & (6.1978) \\
\hline & $27.4969 * * *$ & $44.3110 * * *$ & $82.2134 * * *$ \\
\hline \multirow[t]{2}{*}{ Fish } & (7.5175) & $(6.7365)$ & $(6.5007)$ \\
\hline & $165.2576 * * *$ & $201.8291 * * *$ & $152.4431^{* * *}$ \\
\hline \multirow{2}{*}{ Habitat } & (14.6236) & (11.1838) & (9.5829) \\
\hline & $133.3908 * * *$ & -25.7249 & $170.1484^{* * *}$ \\
\hline \multirow[t]{2}{*}{ Small-size*age } & $(41.2960)$ & (16.6604) & $(16.0232)$ \\
\hline & $140.4976 * * *$ & -19.7655 & $186.2318^{* * *}$ \\
\hline \multirow[t]{2}{*}{ Large-size*age } & (41.0388) & (17.7201) & (17.0909) \\
\hline & 33.7738 & -7.8129 & $61.6957 * * *$ \\
\hline \multirow[t]{2}{*}{ Oil/gas*age } & $(22.0476)$ & $(8.0972)$ & (7.1841) \\
\hline & 11.2708 & $-18.7839 * *$ & $65.8444^{* * *}$ \\
\hline \multirow[t]{2}{*}{ Fish*age } & (22.9338) & $(8.7613)$ & (8.9848) \\
\hline & $93.1677^{* * *}$ & -13.4736 & $118.3180 * * *$ \\
\hline Habitat*age & (26.8177) & (11.8109) & (12.1190) \\
\hline $\begin{array}{l}\text { Price (in preference } \\
\text { space) }\end{array}$ & $\begin{array}{c}77.3265^{* * *} \\
(6.5145)\end{array}$ & $\begin{array}{c}77.0260 * * * \\
(9.6061)\end{array}$ & $\begin{array}{c}143.9347^{* * *} \\
(11.9415)\end{array}$ \\
\hline$N$ & 4683 & & 4683 \\
\hline
\end{tabular}

512 MXL: LogLikelihood $=-3424.973, A I C / n=1.4962$, pseudo $-R 2=0.3255$

513 MNL: LogLikelihood $=-4718.3075, A I C / n=2.0198$, pseudo $-R 2=0.0708$ 
514 Table A4

515

516

517
Marginal willingness to pay (WTP) estimates in Euro resulting from the MNL and MXL models including interactions with the number of adults in respondents' household. ***, ** and * indicate estimates significant at $1 \%$, $5 \%$ and $10 \%$ level, respectively.

\begin{tabular}{l|ccc}
\hline & MNL model & \multicolumn{2}{c}{ MXL model } \\
\cline { 2 - 4 } & Coefficient & Mean & Std.dev. \\
& $($ s.e. & $($ s.e.) & $($ s.e.) \\
Small-size & -11.8140 & $25.7892^{* * *}$ & $200.4595^{* * *}$ \\
& $(10.6661)$ & $(9.8439)$ & $(15.3289)$ \\
Large-size & $21.6590^{* *}$ & $35.1875^{* * *}$ & $262.2640^{* * *}$ \\
& $(10.1674)$ & $(9.8943)$ & $(15.8401)$ \\
Oil/gas & 11.9676 & 13.4038 & $106.3659^{* * *}$ \\
& $(6.6731)$ & $(7.3299)$ & $(7.2783)$ \\
Fish & $28.5654 * * *$ & $21.0283^{* * *}$ & $97.6329 * * *$ \\
& $(7.1847)$ & $(7.3327)$ & $(6.6465)$ \\
Habitat & $173.9335^{* * *}$ & $163.3156 * * *$ & $154.2273^{* * *}$ \\
& $(15.0483)$ & $(10.9335)$ & $(11.0068)$ \\
Small-size*hha & $-25.3816 * *$ & -4.9400 & $122.4152^{* * *}$ \\
& $(10.7765)$ & $(18.2107)$ & $(23.0915)$ \\
Large-size*hha & $-32.7543^{* * *}$ & -20.9364 & $149.1938^{* * *}$ \\
& $(10.8326)$ & $(20.0943)$ & $(24.8135)$ \\
Oil/gas*hha & 0.7950 & 3.5770 & $59.7082^{* * *}$ \\
& $(7.1545)$ & $(12.5101)$ & $(12.1311)$ \\
Fish*hha & -0.1698 & 2.3496 & $63.6251^{* * *}$ \\
& $(7.4223)$ & $(10.3457)$ & $(11.9274)$ \\
Habitat*hha & -1.4092 & -11.7137 & $132.9072^{* * *}$ \\
Price (in preference & $(8.0611)$ & $(15.2722)$ & $(17.8534)$ \\
space) & $77.0887^{* * *}$ & $82.7339^{* * *}$ & $111.8290^{* * *}$ \\
& $(6.4900)$ & $(8.5124)$ & $(11.0080)$ \\
$N$ & & & \\
& 4683 & & 4683 \\
\hline
\end{tabular}

518 MXL: LogLikelihood $=-3442.8638, A I C / n=1.5038$, pseudo $-R 2=0.322$

$519 M N L$ : LogLikelihood $=-4746.7894, A I C / n=2.032$, pseudo $-R 2=0.0652$ 
520 Table $A 5$

521

522

523

Marginal willingness to pay (WTP) estimates in Euro resulting from the MNL and MXL models including interactions with respondents' number of children in the household. ${ }^{* * *},{ }^{* *}$ and $*$ indicate estimates significant at $1 \%, 5 \%$ and 10\% level, respectively.

\begin{tabular}{|c|c|c|c|}
\hline & \multirow{2}{*}{$\begin{array}{c}\text { MNL model } \\
\text { Coefficient } \\
\text { (s.e.) }\end{array}$} & \multicolumn{2}{|c|}{ MXL model } \\
\hline & & $\begin{array}{l}\text { Mean } \\
\text { (s.e.) }\end{array}$ & $\begin{array}{l}\text { Std.dev. } \\
\text { (s.e.) }\end{array}$ \\
\hline & -13.3010 & $53.1869 * * *$ & $164.2629 * * *$ \\
\hline \multirow[t]{2}{*}{ Small-size } & (10.7211) & $(10.2026)$ & (15.7049) \\
\hline & $20.4785^{* *}$ & $76.2262 * * *$ & $227.5745^{* * *}$ \\
\hline \multirow{2}{*}{ Large-size } & (10.1857) & (10.0514) & $(16.2270)$ \\
\hline & 12.0069 & $19.5160 * * *$ & $70.7980 * * *$ \\
\hline \multirow[t]{2}{*}{ Oil/gas } & $(6.6786)$ & $(6.5856)$ & (7.1950) \\
\hline & $28.7149 * * *$ & $27.3992 * * *$ & $93.9699 * * *$ \\
\hline \multirow[t]{2}{*}{ Fish } & (7.1968) & (6.4849) & (7.7029) \\
\hline & $174.3056 * * *$ & $151.9601 * * *$ & $180.9822^{* * *}$ \\
\hline \multirow[t]{2}{*}{ Habitat } & (15.0928) & (11.4279) & $(12.1278)$ \\
\hline & $-21.1655^{* *}$ & -17.5428 & $154.5121^{* * *}$ \\
\hline \multirow[t]{2}{*}{ Small-size*hhc } & (10.5523) & (15.1447) & $(16.5092)$ \\
\hline & -15.6699 & -8.8567 & $164.9145^{* * *}$ \\
\hline \multirow[t]{2}{*}{ Large-size*hhc } & (10.3815) & (16.2101) & $(16.8007)$ \\
\hline & 4.6687 & 6.7790 & $79.0411^{* * *}$ \\
\hline \multirow[t]{2}{*}{ Oil/gas*hhc } & $(6.8014)$ & (9.2063) & (8.7229) \\
\hline & 7.1066 & 7.1389 & $66.4795^{* * *}$ \\
\hline \multirow[t]{2}{*}{ Fish*hhc } & (7.1383) & $(8.3740)$ & $(10.8303)$ \\
\hline & 5.4087 & 13.8456 & $120.4279 * * *$ \\
\hline Habitat*hhc & (7.7207) & (14.3369) & (14.5313) \\
\hline $\begin{array}{l}\text { Price (in preference } \\
\text { space) }\end{array}$ & $\begin{array}{c}76.9809 * * * \\
(6.4867)\end{array}$ & $\begin{array}{c}90.1376 * * * \\
(8.6879)\end{array}$ & $\begin{array}{c}128.1923 * * * \\
(10.7849)\end{array}$ \\
\hline N & 4683 & & 4683 \\
\hline
\end{tabular}

524 MXL: LogLikelihood $=-3436.0707, A I C / n=1.5009$, pseudo- $R 2=0.3233$

$525 M N L:$ LogLikelihood $=-4757.3993, A I C / n=2.0365$, pseudo- $R 2=0.0631$ 

and MXL models including interactions with respondents' personal income level. ${ }^{* * *},{ }^{* *}$ and $*$ indicate estimates significant at $1 \%, 5 \%$ and $10 \%$ level, respectively.

\begin{tabular}{l|ccc}
\hline & MNL model & \multicolumn{2}{c}{ MXL model } \\
\cline { 2 - 4 } & Coefficient & Mean & Std.dev. \\
& $($ s.e. & $($ s.e.) & $($ s.e.) \\
Small-size & -10.8229 & $55.8112^{* * *}$ & $179.8279^{* * *}$ \\
& $(10.6811)$ & $(6.4389)$ & $(12.9113)$ \\
Large-size & $22.4657^{* *}$ & $68.8861^{* * *}$ & $217.8179^{* * *}$ \\
& $(10.1992)$ & $(6.2275)$ & $(13.5462)$ \\
Oil/gas & 11.6468 & $26.6931^{* * *}$ & $68.0622^{* * *}$ \\
& $(6.6842)$ & $(5.1228)$ & $(6.3027)$ \\
Fish & $28.1360^{* * *}$ & $42.0193^{* * *}$ & $94.7217^{* * *}$ \\
& $(7.1917)$ & $(6.2412)$ & $(5.9729)$ \\
Habitat & $174.3198^{* * *}$ & $173.6742^{* * *}$ & $170.3706^{* * *}$ \\
& $(15.0923)$ & $(10.6594)$ & $(10.6996)$ \\
Small-size*pincome & $23.7176^{* *}$ & -6.4925 & $87.6955^{* * *}$ \\
& $(10.3797)$ & $(14.8224)$ & $(13.9267)$ \\
Large-size*pincome & $32.6957^{* * *}$ & -1.2910 & $132.0466^{* * *}$ \\
& $(10.4923)$ & $(14.2723)$ & $(10.9578)$ \\
Oil/gas*pincome & 4.2861 & 12.0139 & $87.0703^{* * *}$ \\
& $(6.5967)$ & $(7.8879)$ & $(7.6481)$ \\
Fish*pincome & 13.3946 & $22.4610^{* * *}$ & $67.3082^{* * *}$ \\
& $(6.9835)$ & $(7.9653)$ & $(8.8072)$ \\
Habitat*pincome & 4.5116 & 20.3780 & $94.8509^{* * *}$ \\
Price (in preference & $(7.4466)$ & $(11.0017)$ & $(12.2034)$ \\
space) & $77.0632^{* * *}$ & $90.6151^{* * *}$ & $157.6493^{* * *}$ \\
& $(6.4886)$ & $(10.4568)$ & $(13.2144)$ \\
$N$ & & & \\
& 4683 & & 4683 \\
\hline
\end{tabular}

530 MXL: LogLikelihood $=-3434.8275, A I C / n=1.5004$, pseudo- $R 2=0.3235$

531 MNL: LogLikelihood $=-4736.1811, A I C / n=2.0274$, pseudo $-R 2=0.0673$ 
532 Table $A 7$

533

534

535
Marginal willingness to pay (WTP) estimates in Euro resulting from the MNL and MXL models including interactions with respondents' household income level. ${ }^{* * *},{ }^{* *}$ and $*$ indicate estimates significant at $1 \%, 5 \%$ and $10 \%$ level, respectively.

\begin{tabular}{l|ccc}
\hline & MNL model & \multicolumn{2}{c}{ MXL model } \\
\cline { 2 - 4 } & Coefficient & Mean & Std.dev. \\
& $($ s.e. & $($ s.e.) & $($ s.e.) \\
Small-size & -13.3661 & $35.0046^{* * *}$ & $219.7241^{* * *}$ \\
& $(10.7271)$ & $(8.7921)$ & $(17.0922)$ \\
Large-size & $20.4588^{* *}$ & $51.5938^{* * *}$ & $290.3487^{* * *}$ \\
& $(10.1862)$ & $(9.6956)$ & $(18.9990)$ \\
Oil/gas & 11.9487 & 10.6724 & $92.8634^{* * *}$ \\
& $(6.6821)$ & $(6.2237)$ & $(6.4229)$ \\
Fish & $28.7103^{* * *}$ & $19.4476^{* * *}$ & $106.0714^{* * *}$ \\
& $(7.1988)$ & $(7.2791)$ & $(7.4993)$ \\
Habitat & $174.4173^{* * *}$ & $163.5352^{* * *}$ & $162.0451^{* * *}$ \\
& $(15.1024)$ & $(10.3174)$ & $(10.3414)$ \\
Small-size*hincome & $-21.5045^{* *}$ & $-64.8025^{* * *}$ & $136.2588^{* * *}$ \\
& $(10.0943)$ & $(19.5461)$ & $(16.2863)$ \\
Large-size*hincome & -15.3735 & $-69.4303^{* * *}$ & $153.1686^{* * *}$ \\
& $(10.0542)$ & $(21.0146)$ & $(17.1366)$ \\
Oil/gas*hincome & 0.0982 & 3.6705 & $51.3623^{* * *}$ \\
& $(6.6196)$ & $(8.6577)$ & $(9.5468)$ \\
Fish*hincome & 3.7842 & -0.3982 & $65.2110^{* * *}$ \\
& $(6.8867)$ & $(9.4339)$ & $(9.7769)$ \\
Habitat*hincome & 9.3989 & 24.3025 & $99.8747^{* * *}$ \\
Price (in preference & $(7.5010)$ & $(13.1462)$ & $(11.5908)$ \\
space) & $76.9715^{* * *}$ & $98.3476^{* * *}$ & $129.4465^{* * *}$ \\
& $(6.4854)$ & $(9.0473)$ & $(11.3568)$ \\
$N$ & & & \\
& 4683 & & 4683 \\
\hline
\end{tabular}

536 MXL: LogLikelihood $=-3424.7189, A I C / n=1.4961$, pseudo- $R 2=0.3255$

537 MNL: LogLikelihood $=-4757.0199, A I C / n=2.0363$, pseudo $-R 2=0.0632$ 
538 Table $A 8$

539

540

541
Marginal willingness to pay (WTP) estimates in Euro resulting from the MNL and MXL models including interactions with respondents' education levels. $* * *, * *$ and $*$ indicate estimates significant at 1\%, 5\% and $10 \%$ level, respectively.

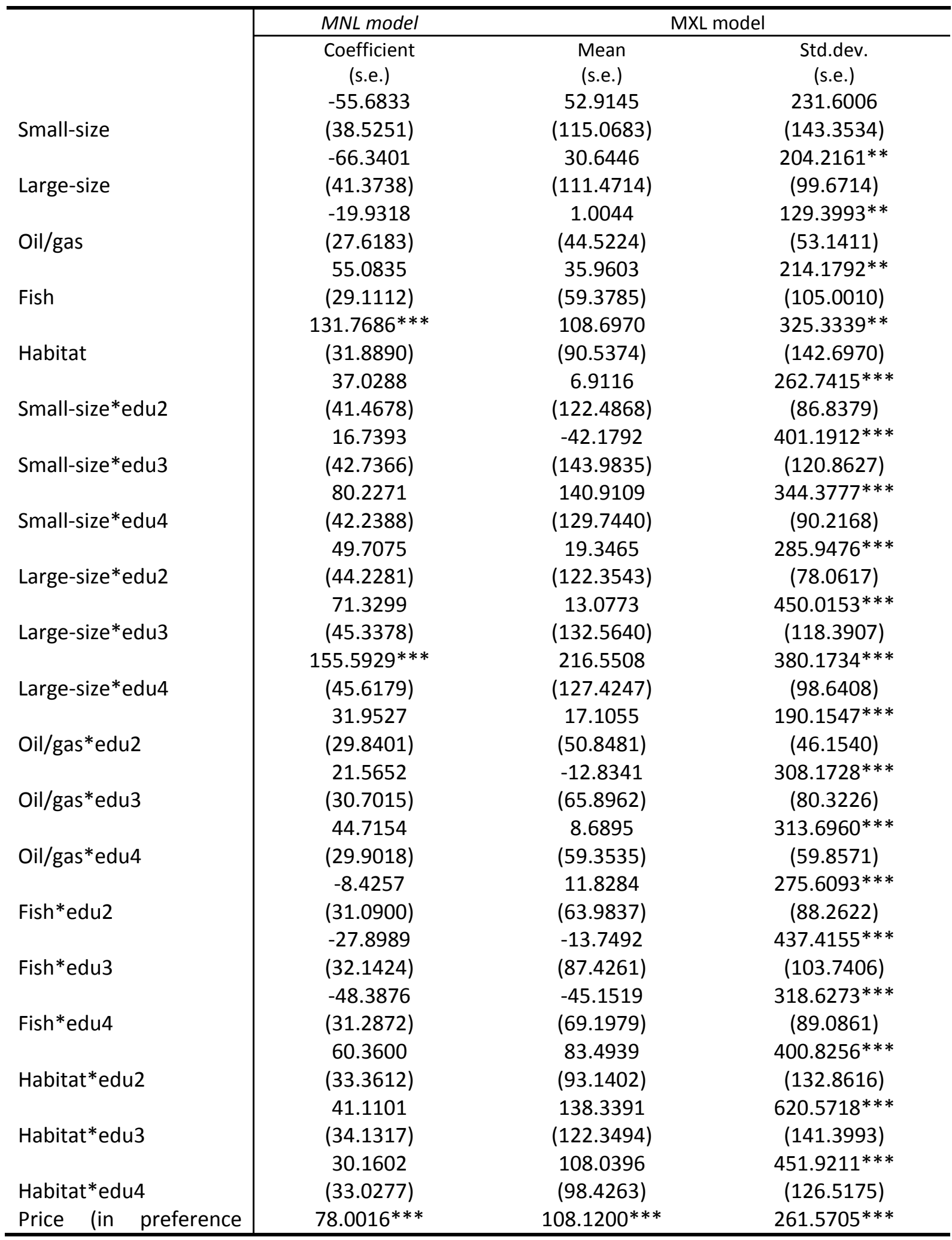


$542 \frac{N}{M X L: \text { LogLikelihood }=-3292.3705, A / C / n=1.5199, \text { pseudo- } R 2=0.3516}$

(6.5179) (22.7911) (27.6411)

space)

4683

543 MNL: LogLikelihood $=-4725.1207, A I C / n=2.027$, pseudo $-R 2=0.0694$

544 
545 Table A9

546

547

548

Marginal willingness to pay (WTP) estimates in Euro resulting from the MNL and MXL models including interactions with respondents living in coastal areas. ${ }^{* * *},{ }^{* *}$ and $*$ indicate estimates significant at $1 \%, 5 \%$ and $10 \%$ level, respectively.

\begin{tabular}{|c|c|c|c|}
\hline & \multirow{2}{*}{$\begin{array}{l}\text { MNL model } \\
\text { Coefficient } \\
\text { (s.e.) }\end{array}$} & \multicolumn{2}{|c|}{ MXL model } \\
\hline & & $\begin{array}{l}\text { Mean } \\
\text { (s.e.) }\end{array}$ & $\begin{array}{l}\text { Std.dev. } \\
\text { (s.e.) }\end{array}$ \\
\hline & 6.2126 & $74.4385^{* * *}$ & $238.1861 * * *$ \\
\hline \multirow[t]{2}{*}{ Small-size } & (12.7402) & (14.4840) & (21.5538) \\
\hline & $41.5929 * * *$ & $75.5606 * * *$ & $324.8072^{* * *}$ \\
\hline \multirow{2}{*}{ Large-size } & (12.4917) & (16.6944) & $(23.9982)$ \\
\hline & $19.6872 * *$ & 1.4302 & $101.9891^{* * *}$ \\
\hline \multirow[t]{2}{*}{ Oil/gas } & (8.3170) & (8.6984) & (8.0898) \\
\hline & $27.0160 * * *$ & $30.2755^{* * *}$ & $90.3740^{* * *}$ \\
\hline \multirow[t]{2}{*}{ Fish } & (8.7904) & (8.1645) & (7.5614) \\
\hline & $157.6426 * * *$ & $145.5596 * * *$ & $138.2143 * * *$ \\
\hline \multirow[t]{2}{*}{ Habitat } & (14.9098) & (11.3516) & $(10.2727)$ \\
\hline & $-52.7171 * *$ & -54.7066 & $213.6329 * * *$ \\
\hline \multirow[t]{2}{*}{ Small-size*coast } & $(21.1806)$ & (35.8184) & $(38.7826)$ \\
\hline & $-57.2663 * * *$ & -26.2789 & $183.5715^{* * *}$ \\
\hline \multirow[t]{2}{*}{ Large-size*coast } & $(21.4707)$ & (37.7308) & $(36.4916)$ \\
\hline & -21.7808 & 14.4083 & $162.9807^{* * *}$ \\
\hline \multirow[t]{2}{*}{ Oil/gas*coast } & (14.0368) & (18.0372) & $(21.1854)$ \\
\hline & 4.6669 & 13.6939 & $137.0991 * * *$ \\
\hline \multirow[t]{2}{*}{ Fish*coast } & (14.4294) & $(21.3065)$ & $(17.6839)$ \\
\hline & $45.4377 * * *$ & $97.4720 * * *$ & $229.7873 * * *$ \\
\hline Habitat*coast & (16.1126) & $(30.9601)$ & $(32.7702)$ \\
\hline $\begin{array}{l}\text { Price (in preference } \\
\text { space) }\end{array}$ & $\begin{array}{c}77.2147^{* * *} \\
(6.4935)\end{array}$ & $\begin{array}{c}67.5253^{* * *} \\
(9.1344)\end{array}$ & $\begin{array}{c}116.1603 * * * \\
(11.3757)\end{array}$ \\
\hline$N$ & 4683 & & 4683 \\
\hline
\end{tabular}


551 Table A10

552

553

554
Marginal willingness to pay (WTP) estimates in Euro resulting from the MNL and MXL models including interactions with respondents living in urban areas. $* * *, * *$ and $*$ indicate estimates significant at 1\%, 5\% and $10 \%$ level, respectively.

\begin{tabular}{|c|c|c|c|}
\hline & \multirow{2}{*}{$\begin{array}{l}\text { MNL model } \\
\text { Coefficient } \\
\text { (s.e.) }\end{array}$} & \multicolumn{2}{|c|}{ MXL model } \\
\hline & & $\begin{array}{l}\text { Mean } \\
\text { (s.e.) }\end{array}$ & $\begin{array}{l}\text { Std.dev. } \\
\text { (s.e.) }\end{array}$ \\
\hline & 1.4810 & $76.3176^{* * *}$ & $226.6086^{* * *}$ \\
\hline \multirow[t]{2}{*}{ Small-size } & (11.9904) & (10.4458) & (17.1932) \\
\hline & $42.5906 * * *$ & $76.3361 * * *$ & $314.1618^{* * *}$ \\
\hline \multirow{2}{*}{ Large-size } & (11.6284) & (11.5579) & (18.8765) \\
\hline & 11.0700 & -11.8093 & $109.4171^{* * *}$ \\
\hline \multirow[t]{2}{*}{ Oil/gas } & $(7.6741)$ & (7.0352) & (7.6410) \\
\hline & $28.2822^{* * *}$ & $18.8630 * * *$ & $103.2025^{* * *}$ \\
\hline \multirow[t]{2}{*}{ Fish } & (8.1878) & (6.6138) & $(6.4224)$ \\
\hline & $170.1934 * * *$ & $150.6411 * * *$ & $145.9575^{* * *}$ \\
\hline \multirow[t]{2}{*}{ Habitat } & $(15.2815)$ & $(9.7687)$ & $(10.1637)$ \\
\hline & $-52.1100 * *$ & -59.1299 & $263.9154^{* * *}$ \\
\hline \multirow[t]{2}{*}{ Small-size*urban } & $(22.6521)$ & (40.4203) & $(57.7426)$ \\
\hline & $-81.5140 * * *$ & -53.9697 & $250.3831^{* * *}$ \\
\hline \multirow[t]{2}{*}{ Large-size* urban } & (23.8207) & (47.9150) & (52.6989) \\
\hline & 3.6153 & 17.9266 & $111.0886 * * *$ \\
\hline \multirow[t]{2}{*}{ Oil/gas*urban } & (15.2150) & (20.9906) & $(26.7661)$ \\
\hline & 1.3837 & 9.7533 & $165.2332^{* * *}$ \\
\hline \multirow[t]{2}{*}{ Fish*urban } & (15.7980) & $(27.2714)$ & $(29.7026)$ \\
\hline & 12.5922 & 43.6612 & $181.9871^{* * *}$ \\
\hline Habitat*urban & (17.0277) & (37.8565) & (32.8401) \\
\hline $\begin{array}{l}\text { Price (in preference } \\
\text { space) }\end{array}$ & $\begin{array}{c}77.4920 * * * \\
(6.4826)\end{array}$ & $\begin{array}{c}84.5579 * * * \\
(9.4224)\end{array}$ & $\begin{array}{c}123.8630 * * * \\
(11.0872)\end{array}$ \\
\hline$N$ & 4683 & & 4683 \\
\hline
\end{tabular}

555

MXL: LogLikelihood $=-3427.2631, \mathrm{AIC} / n=1.4971$, pseudo- $R 2=0.325$

556 MNL: LogLikelihood $=-4748.8291, A I C / n=2.0328$, pseudo $-R 2=0.0648$ 
558 Table A11

559

560
Marginal willingness to pay (WTP) estimates in Euro resulting from the MNL and MXL models including interactions with respondents' work status. ${ }^{* * *},{ }^{* *}$ and ${ }^{*}$ indicate estimates significant at $1 \%, 5 \%$ and $10 \%$ level, respectively.

\begin{tabular}{|c|c|c|c|}
\hline & \multirow{3}{*}{$\begin{array}{c}\text { MNL model } \\
\text { Coefficient } \\
\text { (s.e.) } \\
0.8243\end{array}$} & \multicolumn{2}{|c|}{ MXL model } \\
\hline & & $\begin{array}{l}\text { Mean } \\
\text { (s.e.) }\end{array}$ & $\begin{array}{l}\text { Std.dev. } \\
\text { (s.e.) }\end{array}$ \\
\hline & & -4.4598 & $99.4286^{* * *}$ \\
\hline \multirow[t]{2}{*}{ Small-size } & $(53.8145)$ & $(5.5013)$ & $(7.0368)$ \\
\hline & -22.6067 & $28.4999 * * *$ & $139.5364^{* * *}$ \\
\hline \multirow[t]{2}{*}{ Large-size } & $(55.3865)$ & $(6.0846)$ & (7.4995) \\
\hline & -9.3276 & $13.8304^{* * *}$ & $103.5741 * * *$ \\
\hline \multirow[t]{2}{*}{ Oil/gas } & (38.1438) & $(5.3624)$ & $(6.3692)$ \\
\hline & 46.5242 & 9.0967 & $89.6548 * * *$ \\
\hline \multirow[t]{2}{*}{ Fish } & (39.1668) & $(4.9518)$ & $(5.4167)$ \\
\hline & $115.8885^{* * *}$ & $150.7982 * * *$ & $177.7242^{* * *}$ \\
\hline \multirow[t]{2}{*}{ Habitat } & (42.3707) & (8.7956) & (9.7333) \\
\hline & -59.0539 & -42.3140 & $91.1195^{* * *}$ \\
\hline \multirow[t]{2}{*}{ Small-size*work2 } & (77.7055) & $(21.7354)$ & $(15.2229)$ \\
\hline & -63.7765 & $-109.9586 * * *$ & $194.0534 * * *$ \\
\hline \multirow[t]{2}{*}{ Small-size* work3 } & (73.3517) & (23.7990) & $(29.9280)$ \\
\hline & 30.0249 & 26.7925 & $78.0235^{* * *}$ \\
\hline \multirow[t]{2}{*}{ Small-size*work4 } & (71.5272) & (14.8291) & (13.1569) \\
\hline & -40.4722 & -97.7921 & 56.4045 \\
\hline \multirow[t]{2}{*}{ Small-size*work5 } & (59.4563) & (199.0386) & (155.3539) \\
\hline & -23.1881 & $37.0603 * * *$ & $41.3516^{* * *}$ \\
\hline \multirow[t]{2}{*}{ Small-size* work6 } & (57.0929) & (11.1199) & $(6.5993)$ \\
\hline & 3.2946 & $-84.2646 * *$ & $130.0512^{* * *}$ \\
\hline \multirow[t]{2}{*}{ Small-size*work7 } & $(56.0285)$ & $(33.3054)$ & $(23.5257)$ \\
\hline & -99.1758 & $-85.1258 * * *$ & $97.9256 * * *$ \\
\hline \multirow[t]{2}{*}{ Large-size*work2 } & (83.5497) & $(15.6630)$ & $(10.4383)$ \\
\hline & -32.4732 & $-72.2749 * * *$ & $103.0552^{* * *}$ \\
\hline \multirow{2}{*}{ Large-size*work3 } & (74.7649) & $(24.1403)$ & $(29.0060)$ \\
\hline & 96.7611 & 25.3062 & $55.4858 * * *$ \\
\hline \multirow[t]{2}{*}{ Large-size*work4 } & (71.6394) & $(15.3285)$ & (9.1889) \\
\hline & 43.5072 & -290.5297 & 10.0404 \\
\hline \multirow[t]{2}{*}{ Large-size*work5 } & (60.3195) & (172.6677) & (112.2723) \\
\hline & 49.2485 & -12.2220 & $65.9354 * * *$ \\
\hline \multirow[t]{2}{*}{ Large-size*work6 } & $(58.3403)$ & $(10.2900)$ & $(10.1995)$ \\
\hline & 51.6266 & $-214.1708 * * *$ & $89.9138 * * *$ \\
\hline \multirow[t]{2}{*}{ Large-size* work7 } & (57.6741) & $(40.8379)$ & (32.8634) \\
\hline & 28.8488 & $-36.8899 * * *$ & 45.9670 \\
\hline \multirow[t]{2}{*}{ Oil/gas*work2 } & $(56.7293)$ & (14.2722) & $(25.6822)$ \\
\hline & 9.1289 & -22.2731 & $77.0666 * * *$ \\
\hline \multirow[t]{2}{*}{ Oil/gas*work3 } & (50.3809) & $(22.4920)$ & $(24.5642)$ \\
\hline & -38.2853 & -22.5833 & $47.9016^{* * *}$ \\
\hline \multirow[t]{2}{*}{ Oil/gas*work4 } & (48.2553) & (11.9559) & $(12.3098)$ \\
\hline & -2.5635 & -62.7264 & 50.8726 \\
\hline Oil/gas*work5 & (41.8109) & (121.2017) & (92.4557) \\
\hline
\end{tabular}




\begin{tabular}{|c|c|c|c|}
\hline \multirow{3}{*}{ Oil/gas*work6 } & 38.5565 & -14.4654 & $88.3497^{* * *}$ \\
\hline & (40.1814) & (7.5714) & $(10.8367)$ \\
\hline & 28.4994 & $-80.1940 * *$ & $225.3366 * * *$ \\
\hline \multirow[t]{2}{*}{ Oil/gas*work7 } & (39.6318) & (35.9440) & $(51.0156)$ \\
\hline & -50.2946 & $-53.4141 * * *$ & 15.7781 \\
\hline \multirow[t]{2}{*}{ Fish*work2 } & (58.1704) & (12.5191) & $(29.0962)$ \\
\hline & 31.7633 & 19.9546 & $86.3783^{* * *}$ \\
\hline \multirow[t]{2}{*}{ Fish*work3 } & (53.0338) & (16.1842) & $(11.2102)$ \\
\hline & 15.3837 & $-40.5906 * * *$ & 13.5980 \\
\hline \multirow[t]{2}{*}{ Fish*work4 } & (49.5680) & $(12.7157)$ & (11.0613) \\
\hline & -27.7626 & 107.7791 & 10.3423 \\
\hline \multirow[t]{2}{*}{ Fish*work5 } & (42.9195) & (154.8238) & $(130.2092)$ \\
\hline & -23.8860 & $39.8645^{* * *}$ & $82.0739 * * *$ \\
\hline \multirow[t]{2}{*}{ Fish*work6 } & (41.1161) & (8.9579) & $(7.2864)$ \\
\hline & -18.0226 & $95.5073 * * *$ & 23.5889 \\
\hline \multirow[t]{2}{*}{ Fish*work7 } & (40.5592) & $(26.4269)$ & $(25.0750)$ \\
\hline & $145.4365^{* *}$ & -15.0874 & $99.3458 * * *$ \\
\hline \multirow[t]{2}{*}{ Habitat*work2 } & (65.7442) & (13.1524) & (15.1267) \\
\hline & 92.1813 & $94.2700 * *$ & $197.3185^{* * *}$ \\
\hline \multirow[t]{2}{*}{ Habitat*work3 } & (56.6761) & $(44.0982)$ & (45.9819) \\
\hline & 81.8422 & $-45.9610 * * *$ & 3.9604 \\
\hline \multirow[t]{2}{*}{ Habitat*work4 } & (53.9822) & $(15.0920)$ & $(6.2831)$ \\
\hline & 57.5358 & -160.0537 & 9.9769 \\
\hline \multirow[t]{2}{*}{ Habitat*work5 } & (46.0944) & (162.5293) & (118.2894) \\
\hline & 65.2822 & $-43.7796 * * *$ & $95.7271^{* * *}$ \\
\hline \multirow[t]{2}{*}{ Habitat*work6 } & $(44.2724)$ & (10.8374) & $(7.3684)$ \\
\hline & 47.7620 & $240.2054 * * *$ & $170.0890 * * *$ \\
\hline Habitat*work7 & $(43.4363)$ & (46.9806) & $(32.4517)$ \\
\hline $\begin{array}{l}\text { Price (in preference } \\
\text { space) }\end{array}$ & $\begin{array}{l}76.9657^{* * *} \\
(6.5106)\end{array}$ & $\begin{array}{c}99.4778 * * * \\
(9.4338)\end{array}$ & $\begin{array}{c}129.0380 * * * \\
(9.8407)\end{array}$ \\
\hline$N$ & 4683 & & 4683 \\
\hline
\end{tabular}


563

Table A12

564

565

566
Marginal willingness to pay (WTP) estimates in Euro resulting from the MNL and MXL models including interactions with respondents' occupation type. ***, ** and * indicate estimates significant at 1\%, 5\% and $10 \%$ level, respectively.

\begin{tabular}{|c|c|c|c|}
\hline & \multirow{2}{*}{$\begin{array}{c}\text { MNL model } \\
\text { Coefficient } \\
\text { (s.e.) }\end{array}$} & \multicolumn{2}{|c|}{ MXL model } \\
\hline & & $\begin{array}{l}\text { Mean } \\
\text { (s.e.) }\end{array}$ & $\begin{array}{c}\text { Std.dev. } \\
\text { (s.e.) }\end{array}$ \\
\hline & 0.8243 & 40.0654 & $75.1364^{* * *}$ \\
\hline \multirow{2}{*}{ Small-size } & (53.8145) & (28.9481) & (7.4301) \\
\hline & -22.6067 & -17.8618 & $112.3242 * * *$ \\
\hline \multirow{2}{*}{ Large-size } & (55.3865) & (37.7711) & (7.3381) \\
\hline & -9.3276 & 1.8871 & $64.8042 * * *$ \\
\hline \multirow[t]{2}{*}{ Oil/gas } & (38.1438) & (30.3730) & (6.3397) \\
\hline & 46.5242 & -3.7888 & $83.4676 * * *$ \\
\hline \multirow[t]{2}{*}{ Fish } & (39.1668) & (36.5764) & (5.4995) \\
\hline & $115.8885^{* * *}$ & 63.2686 & $143.6640 * * *$ \\
\hline \multirow[t]{2}{*}{ Habitat } & (42.3707) & (39.9699) & (7.8136) \\
\hline & -59.0539 & -62.8797 & 150.5327 \\
\hline \multirow[t]{2}{*}{ Small-size*occ2 } & (77.7055) & (94.4512) & (306.1169) \\
\hline & -63.7765 & -73.0461 & 48.6550 \\
\hline \multirow[t]{2}{*}{ Small-size*occ3 } & (73.3517) & (61.5627) & (68.1144) \\
\hline & 30.0249 & -3.6943 & $109.7413^{* *}$ \\
\hline \multirow[t]{2}{*}{ Small-size*occ4 } & (71.5272) & $(54.0475)$ & $(44.8146)$ \\
\hline & -40.4722 & $-81.9716^{* *}$ & 37.1030 \\
\hline \multirow[t]{2}{*}{ Small-size*occ5 } & (59.4563) & (33.1342) & (20.0224) \\
\hline & -23.1881 & -14.0227 & $69.2227^{* * *}$ \\
\hline \multirow[t]{2}{*}{ Small-size*occ6 } & (57.0929) & (30.6159) & $(9.7131)$ \\
\hline & 3.2946 & -13.0255 & $59.5792 * * *$ \\
\hline \multirow[t]{2}{*}{ Small-size*occ7 } & (56.0285) & (29.9436) & $(11.3611)$ \\
\hline & -99.1758 & -18.6939 & 99.7828 \\
\hline \multirow[t]{2}{*}{ Large-size*occ2 } & (83.5497) & (140.4622) & (374.2790) \\
\hline & -32.4732 & -11.9533 & 108.4073 \\
\hline \multirow[t]{2}{*}{ Large-size*occ3 } & (74.7649) & (60.1130) & (121.8136) \\
\hline & 96.7611 & 51.9102 & $114.1404^{* *}$ \\
\hline \multirow[t]{2}{*}{ Large-size*occ4 } & (71.6394) & (60.2978) & (47.3959) \\
\hline & 43.5072 & 36.9308 & $103.7293 * * *$ \\
\hline \multirow[t]{2}{*}{ Large-size*occ5 } & (60.3195) & (43.4449) & $(23.6780)$ \\
\hline & 49.2485 & 55.1878 & $110.7137^{* * *}$ \\
\hline \multirow[t]{2}{*}{ Large-size*occ6 } & (58.3403) & (39.1985) & (13.9700) \\
\hline & 51.6266 & 28.3444 & $86.5913^{* * *}$ \\
\hline \multirow[t]{2}{*}{ Large-size*occ7 } & (57.6741) & (37.9817) & $(10.6756)$ \\
\hline & 28.8488 & 47.7096 & 157.2712 \\
\hline \multirow[t]{2}{*}{ Oil/gas*occ2 } & (56.7293) & $(249.9466)$ & $(147.0846)$ \\
\hline & 9.1289 & -68.3551 & 147.1971 \\
\hline \multirow[t]{2}{*}{ Oil/gas*occ3 } & (50.3809) & (63.2195) & (78.9228) \\
\hline & -38.2853 & -46.6308 & 4.6825 \\
\hline Oil/gas*occ4 & (48.2553) & (44.8319) & (47.1852) \\
\hline Oil/gas*occ5 & -2.5635 & -22.2961 & $120.2258^{* * *}$ \\
\hline
\end{tabular}




\begin{tabular}{|c|c|c|c|}
\hline & (41.8109) & (37.6613) & $(20.9903)$ \\
\hline & 38.5565 & 10.0195 & $112.9328 * * *$ \\
\hline \multirow{2}{*}{ Oil/gas*occ6 } & $(40.1814)$ & (32.2823) & $(12.2452)$ \\
\hline & 28.4994 & -4.7238 & $69.9387^{* * *}$ \\
\hline \multirow[t]{2}{*}{ Oil/gas*occ7 } & (39.6318) & (31.5316) & (7.9691) \\
\hline & -50.2946 & 24.8506 & 72.6734 \\
\hline \multirow{2}{*}{ Fish*occ2 } & (58.1704) & (86.4067) & (48.7868) \\
\hline & 31.7633 & 77.3235 & 90.7642 \\
\hline \multirow[t]{2}{*}{ Fish*occ3 } & (53.0338) & (68.9325) & (88.9028) \\
\hline & 15.3837 & 64.3431 & 52.3107 \\
\hline \multirow{2}{*}{ Fish*occ4 } & (49.5680) & (56.8906) & (51.8468) \\
\hline & -27.7626 & 11.3251 & $63.5381 * * *$ \\
\hline \multirow[t]{2}{*}{ Fish*occ5 } & (42.9195) & (39.3054) & $(17.5203)$ \\
\hline & -23.8860 & 3.4640 & $97.7757^{* * *}$ \\
\hline \multirow[t]{2}{*}{ Fish*occ6 } & (41.1161) & $(37.8580)$ & $(17.9779)$ \\
\hline & -18.0226 & 32.7861 & $64.1400 * * *$ \\
\hline \multirow[t]{2}{*}{ Fish*occ7 } & $(40.5592)$ & (37.3949) & $(8.7673)$ \\
\hline & $145.4365^{* *}$ & 158.6720 & 132.1360 \\
\hline \multirow[t]{2}{*}{ Habitat*occ2 } & $(65.7442)$ & $(169.1785)$ & (275.8064) \\
\hline & 92.1813 & $160.5170 * *$ & 49.2630 \\
\hline \multirow[t]{2}{*}{ Habitat*occ3 } & $(56.6761)$ & (62.8941) & (52.9652) \\
\hline & 81.8422 & 104.3213 & 70.1460 \\
\hline \multirow[t]{2}{*}{ Habitat*occ4 } & (53.9822) & $(62.8461)$ & (122.1107) \\
\hline & 57.5358 & 58.2237 & $77.0704^{* *}$ \\
\hline \multirow[t]{2}{*}{ Habitat*occ5 } & (46.0944) & $(45.3086)$ & (33.6302) \\
\hline & 65.2822 & $96.2504^{* *}$ & $207.7326 * * *$ \\
\hline \multirow[t]{2}{*}{ Habitat*occ6 } & $(44.2724)$ & $(42.0687)$ & $(20.5507)$ \\
\hline & 47.7620 & 62.2234 & $53.2077 * * *$ \\
\hline Habitat*occ7 & (43.4363) & (40.7806) & (9.6610) \\
\hline $\begin{array}{l}\text { Price (in preference } \\
\text { space) }\end{array}$ & $\begin{array}{c}76.9657^{* * *} \\
(6.5106)\end{array}$ & $\begin{array}{c}97.9444 * * * \\
(8.9500)\end{array}$ & $\begin{array}{c}134.0622^{* * *} \\
(11.9855)\end{array}$ \\
\hline$N$ & 4683 & & 4683 \\
\hline
\end{tabular}




\section{References}

Armstrong, C.W, Foley, N.S., Kahui, V. and Grehan, A., 2014. Cold water coral reef management from an ecosystem service perspective. Marine Policy 50, 125-134

Christie, M., Hanley, N., Warren, J., Murphy, K., Wright, R., Hyde, T., 2006. Valuing the diversity of biodiversity. Ecological Economics 58, 304-317

Colombo S., Christie M., Hanley, N., 2013. What are the consequences of ignoring attributes in choice experiments? Implications for ecosystem service values. Ecological Economics 96, 25-35

Czajkowski, M., Hanley, N. and LaRiviere, J., 2015. The Effects of Experience on Preference Uncertainty: Theory and Empirics for Public and Quasi-Public Environmental Goods. American Journal of Agricultural Economics, 97 (1) 333-351.

Edinger, E. N., Wareham, V.E., Haedrich, R.L., 2007. Patterns of groundfish diversity and abundance in relation to deep-sea coral distributions in newfoundland and labrador waters. Bulletin of Marine Science 81 (Supplement 1), 101-122.

Foley, N., Rensburg, T.M.v., Armstrong, C.W., 2010. The ecological and economic value of cold-water coral ecosystems. Ocean \& Coastal Management 53, 313-326

Fosså, J.H., Mortensen, P.B., Furevik, D., 2002. The deep water coral lophelia pertusa in Norwegian waters: Distribution and fishery impacts. Hydrobiologia 471, 1-12

Funk, P., Gathmann, C., 2008. Gender gaps in policy making. Evidence from direct democracy in Switzerland. Economics Working paper 1126. Department of Economics and Business, University of Pompeu Fabra 
599 Glenn, H., Wattage, P., Mardle, S., Rensburg, T.M.v., Grehan, A., Foley, N., 2010. Marine

600 protected areas - substantiating their worth. Marine Policy 34, 421-430

601

Groot, R.d., Brander, L., Ploeg, S.v.d., Costanza, R., Bernard, F., Braat, L., Christie, M., Crossman, N., Gehmandi, A., Hein, L., Hussain, S., Kumar, P., McVittie, A., Portela, R., Rodriguez, L.C., Brink, P.T., Beukering, P.v., 2012. Global estimates of the value of ecosystems and their services in monetary units. Ecosystem Services 1, 50-61

606

Hanemann, W. M., 1984. Welfare Evaluations in Contingent Valuation Experiments with

Discrete Responses. American Journal of of Agricultural Economics, 66(3):332-341.

609

Hynes, S., Hanley, N., Tinch, D., 2013. Valuing improvements to coastal waters using choice experiments: an application to revisions of the EU Bathing Waters Directive. Marine Policy 40, 137-144.

613

IMR (Institute of Marine Research), 2012. Home page article by Mortensen, P.B., Mortensen, http://www.imr.no/nyhetsarkiv/2012/oktober/nye_korallrev_utenfor_trondelag_og_more/ en

Jobstvogt, N., Hanley, N., Hynes, S., Kenter, J., Witte, U., 2014. Twenty thousand sterling under the sea: Estimating the value of protecting deep-sea biodiversity. Ecological Economics 97, 10-19. 
627 Leggett, C.G., KLeckner, N.S., Boyle, K.J., Duffield, J.W., Mitchell, R.C., 2003. Social desirability 628 bias in contingent valuation surveys administered through in-person interviews. Land Economics 79, 561-575

630

List, J.A., Berrens, R.P., Bohara, A.K., Kerkvliet, J., 2004. Examining the role of social isolation on stated preferences. The American Economic Review 94, 741-752 of wild goose conservation: a comparison of interview and group-based approaches. Ecological Economics 43, 49-59.

MacMillan, D., Hanley, N., Lienhoop, N., 2006. Contingent Valuation: Environmental polling

Martín-López B, Iniesta-Arandia I, García-Llorente M, Palomo I, Casado-Arzuaga I, et al. e38970. doi:10.1371/journal.pone.0038970

McFadden, D.L., 1974. Conditional Logit Analysis of Qualitative Choice Behavior. In P.

Millennium Ecosystem Assessment, 2005. Ecosystems and human wellbeing. Synthesis. 
654

655

656

657

658

659

660

661

662

663

664

665

666

667

668

669

670

671

672

673

674

675

676

677

678

679

680

Pendelton, L.H., 1995. Valuing coral reef protection. Ocean and Coastal management 26, 119-131

Ramirez-Llodra E, Tyler PA, Baker MC, Bergstad OA, Clark MR, et al. (2011) Man and the Last Great Wilderness: Human Impact on the Deep Sea. PLoS ONE 6(8): e22588.

doi:10.1371/journal.pone.0022588

Ressurreição, A., Gibbons, J., Ponce, T., Kaiser, M., Santos, R. S., Edwards-Jones, G., 2011. Economic valuation of species loss in the open sea. Ecological Economics 70, 729-739.

Revelt, D., Train, K., 1998. Mixed Logit With Repeated Choices: Households' Choices Of Appliance Efficiency Level. The Review of Economics and Statistics 80, 647-657

Rogers, A., 2013. Public and expert preference divergence: evidence from a choice experiment of marine reserves in Australia. Land Economics 89, 346-370

Sandorf, E., Aanesen, M., Navrud, S., 2014. Survey mode effects: Valution workshops versus internet panels. Working paper, Norwegian College of Fisheries Science, University of Tromso, Norway

Sarkis, S., Beukering, P.H.J.v., McKenzie, E., Brander, L., Hess, S., Bervoets, T., Putten, L.L.v.d., Roelfsema, M., 2013, Total Economic Value of Bermuda's Coral Reefs. A summary. In C.R.C.Sheppard (ed) Coral Reefs of the United Kingdom Overseas Territories. Coral reefs of the world vol 4, 2013, 201-211 
683 Scarpa, R., Rose, J.M., 2008. Design efficiency for non-market valuation with choice 684 modelling: how to measure it, what to report and why. Australian Journal of Agricultural and 685 Resource Economics 52, 253-282

686

687

688

689

690

692

693

694

695

696

697

698

699

700

701

702

703

704

705

706

707

708

Small, K. A., and Rosen, H. S., 1981. Applied Welfare Economics with Discrete Choice Models. Econometrica, 49(1):105-130.

Spash, C., 2002. Informing and forming preferences in environmental valuation: Coral reef biodiversity. Economic Psychology 23, 665-687

Spurgeon, J.P.G., 1992. The Economic valuation of Coral Reefs. Marine Pollution Bulletin 24, 529-536

Stone, R. P., 2006. Coral habitat in the Aleutian islands of Alaska: Depth distribution, finescale species associations, and fisheries interactions. Coral Reefs 25, 229-238

Stuart, M., Smout, T.C., 2013. The Firth of Forth: An Environmental History. Birlinn Press, Edinburgh

TEEB, 2010. The Economics of Ecosystems and Biodiversity: Ecological and Economic Foundations. P. Kumar (ed). Earthscan, London and Washington.

Train, K. E., Weeks, M., 2005. Discrete Choice Models in Preference Space and Willingnessto-paySpace. In R. Scarpa and A. Alberini (eds) Applications of Simulation Methods in Environmental and Resource Economics, 1-16, Springer, Dordrecht. 
709 Wilson, M.A., Howarth, R.B., 2002. Discourse-based valuation of ecosystem services:

710 establishing fair outcomes through group deliberation. Ecological Economics 41, 431-443.

711 
$712 \quad$ Table 1

Attributes and attribute levels

\begin{tabular}{|c|c|c|c|c|}
\hline Attribute & $\begin{array}{l}\text { Size of } \\
\text { protected area } \\
\left(\mathrm{km}^{2}\right)\end{array}$ & $\begin{array}{l}\text { Protected area } \\
\text { attractive for oil/gas } \\
\text { and fisheries } \\
\text { activities? }\end{array}$ & $\begin{array}{l}\text { Protected } \\
\text { area } \\
\text { important as } \\
\text { habitat for } \\
\text { fish? }\end{array}$ & $\begin{array}{l}\text { Additional } \\
\text { costs of } \\
\text { protection }\end{array}$ \\
\hline Reference level & 2.445 & Partly & Partly & 0 \\
\hline Level 1 & 5.000 & $\begin{array}{l}\text { Attractive for the } \\
\text { fisheries }\end{array}$ & $\begin{array}{l}\text { Not } \\
\text { Important }\end{array}$ & 100 \\
\hline Level 2 & 10.000 & $\begin{array}{l}\text { Attractive for oil/gas } \\
\text { activities }\end{array}$ & Important & 200 \\
\hline Level 3 & & $\begin{array}{l}\text { Attractive for both } \\
\text { fisheries and oil/gas } \\
\text { activities }\end{array}$ & & 500 \\
\hline Level 4 & & $\begin{array}{l}\text { Neither attractive for } \\
\text { fisheries nor for } \\
\text { oil/gas activities }\end{array}$ & & 1000 \\
\hline
\end{tabular}

713

714 
Individual specific variables overview

\begin{tabular}{|c|c|c|c|c|}
\hline & Lowest value & Highest value & Mean & $\begin{array}{l}\text { Number of } \\
\text { observations }\end{array}$ \\
\hline Gender & 0 (male) & 1 (female) & 0.465 & 394 \\
\hline Age & 18 years & 88 years & 46.6years & 395 \\
\hline ENGO & 0 (not ENGO member) & 1 (ENGO member) & 0.1 & 394 \\
\hline Education & 1 (only obligatory) & 4 (higher deg. Univ.) & 2.84 & 394 \\
\hline $\begin{array}{l}\text { Labor force } \\
\text { participation }\end{array}$ & 0 (not in labor force) & 1 (in labor force) & 0.63 & 393 \\
\hline $\begin{array}{l}\text { Working in the } \\
\text { marine sector }\end{array}$ & 0 (other industries) & 1 (the marine sector) & 0.08 & 391 \\
\hline $\begin{array}{l}\text { Household size } \\
\text { (cont. var.) }\end{array}$ & 1 & 8 & 2.5 & 397 \\
\hline Personal income & 1 (below 200K NOK) & 10 (above 1 mill NOK) & 3.5 & 388 \\
\hline Household income & 1 (below 200K NOK) & 8 (above 1.5 mill NOK) & 3.8 & 385 \\
\hline Coastal areas & 0 (interior areas) & 1 (coastal areas) & 0.63 & 397 \\
\hline Urban areas & 0 (rural areas) & 1 (urban areas) & 0.73 & 397 \\
\hline
\end{tabular}


718 Table 3

719

720

Marginal willingness to pay (WTP) estimates in Euro resulting from the MNL and MXL models. ${ }^{* * *},{ }^{* *}$ and ${ }^{*}$ indicate estimates significant at $1 \%, 5 \%$ and 10\% level, respectively.

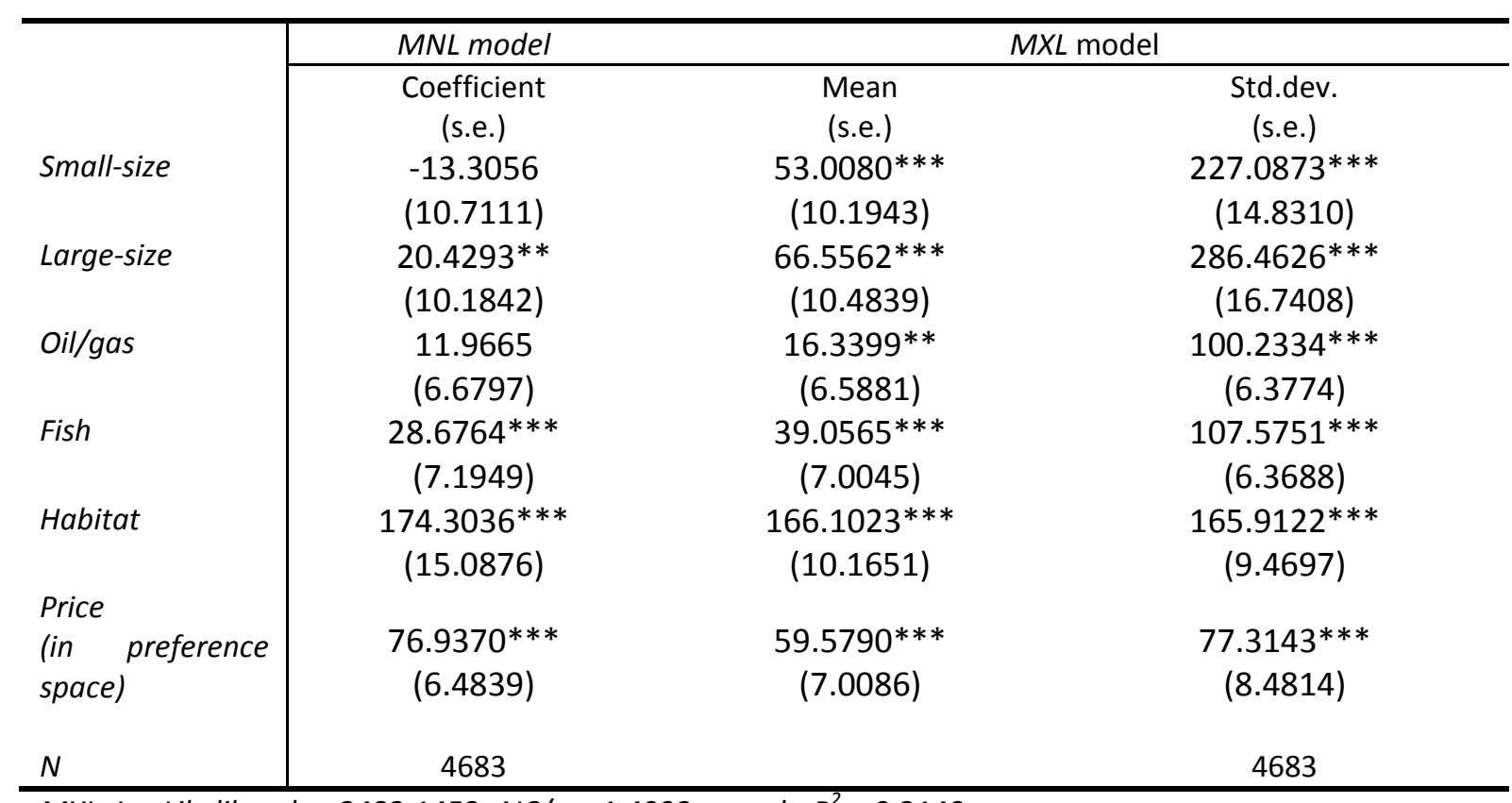

$721 \quad$ MXL: LogLikelihood $=-3483.1453, A I C / n=1.4992$, pseudo $-R^{2}=0.3140$.

722 MNL: LogLikelihood $=-4759.7336, A I C / n=2.0353$, pseudo $-R^{2}=0.0626$.

723

724 
Total WTP per household per year in EUR for small and large protection scenario. $* * *,{ }^{* *}$ and $*$ indicate estimates significant at $1 \%, 5 \%$ and $10 \%$ level, respectively.

\begin{tabular}{|c|c|c|c|c|}
\hline & \multicolumn{2}{|c|}{ MNL model } & \multicolumn{2}{|c|}{ MXL model } \\
\hline & $\begin{array}{l}\text { WTP } \\
\text { (s.e.) }\end{array}$ & 95\% c.i. & $\begin{array}{l}\text { Mean WTP } \\
\text { (s.e.) }\end{array}$ & 95\% c.i. \\
\hline Small protection scenario & $\begin{array}{c}201.58^{* * *} \\
(15.05)\end{array}$ & $172.09-231.08$ & $\begin{array}{c}274.05^{* * *} \\
(15.86)\end{array}$ & $242.98-305.17$ \\
\hline Large protection scenario & $\begin{array}{c}235.28 * * * \\
(16.55)\end{array}$ & $202.83-267.73$ & $\begin{array}{c}287.37 * * * \\
(16.57)\end{array}$ & $254.92-319.84$ \\
\hline
\end{tabular}

